\title{
貨物船垂直撓夕振動の解析
}

\author{
正員 松 浦 義 一* \\ An Analysis of Vertical Vibration of Cargo Ships \\ By Yoshikazu Matsuura, Member
}

Summary

This paper describes, firstly, an analytical method of computing the eigenvalues of vertical vibration of ships taking into account the distribution of mass, the effect of variable section and the effect of shear deflection and rotary inertia. The fundamental equation is solved by Galerkin's method in the form of numerical integration.

For 2 node vertical vibration, the virtual added mass is calculated by Lewis' or Taylor's method and by using it the computed natural frequencies are usually in good agreement with the observed frequencies. For more than 3 node vertical vibration, however, the virtual added mass calculated by Lewis' or Taylor's method results in considerable discrepancy between the computed and observed frequencies.

To explain this discrepancy the author examins the effect of local vibration of ship's bottom on the virtual added mass and obtains a reasonable correction factor for the virtual added mass.

Applying the above described method, an analysis of the vertical vibration of two actual cargo ships is shown, and the computed natural frequencies are in good agreement with the observed frequencies for 2 and 3 node vertical vibration.

緒 言

船体撓み振動の固有振動数の計算法に関しては従来多数の研究が発表されているが，その大部分は最低次の固 有振動数を求める方法であつて, 高次の固有振動数の計算法についてはその研究が極めて少く, 現在の所では熊 井教授(1)の方法が知られており，また 4 節振動程度までの固有振動数の計算法は 2,3 発表されているが(2)(3)(4), 精度の点に拈いてまだ問題があるよ5に思われる。

著者は船体の形状および構造上の特徵をできるだけ忠実に考虑に入れて 4 節振動程度までの固有振動数を実用 上十分な精度で求め得るような計算法を見出す目的を以て，船体振動に影響をおよぼすすべての要素即ち付加水 質量を含めた船体重量の分布形状, 可変断面効果, 船楼の影響, 剪断および回転慣性の影響, 付加水質量の大さ 等をそれぞれ適当な形で考虑に入れて貨物船の場合についてその垂直撓み振動に対して一連の解析を行つた。本 論文はその解析の第 1 段階として船体撓み振動の固有値の計算法を述べ，第 2 段階として船底部の局部振動が船 体の付加水質量におよぼす影響を考虑に入れ，従来の方法による付加水質量の計算値を修正することによつて船 体固有振動数を算定する方法について述べたものである。

\section{I. 船体撓み振動の固有值}

\section{§1. 基礎方程式およびその解法}

船体のごとき複雑な可変断面効果のあるものに対しては前記のすべての要素を考慮に入れた基礎方程式を解く ことは困難であるので，まず重量分布の形状と有効曲げ剛性の分布形状の 2 つ要素を考虑に入れて固有值を求 め，その固有值に対して後述（§ 3）の方法によつて剪断执よび回転慣性の影響を考虑した修正を行なう。

船体の 1 端に原点を採り, 船の長さ方向に $x$ 軸, 垂直下方に $y$ 軸を採り, 後述（§ 4）の方法によつて重量

* 大阪大学工学部 
分布 $m_{x}$ および断面の有効慣性モーメントの分布 $I_{x}$ が与えられたものとし，船体の撓みを $y(x, t)$ とすると 運動方程式は

$$
\frac{\partial^{2}}{\partial x^{2}}\left(E I_{x} \frac{\partial^{2} y}{\partial x^{2}}\right)+\frac{m_{x}}{g} \frac{\partial^{2} y}{\partial t^{2}}=0
$$

となり, $y(x, t)=y(x) \sin \omega t$ と括けば $y(x)$ に関し

$$
\frac{d^{2}}{d x^{2}}\left(I_{x} \frac{d^{2} y}{d x^{2}}\right)-\frac{m_{x} \omega^{2}}{E g} y=0
$$

となる。船の全長を $L$ とし，船体中央断面に打ける $I_{x}$ および $m_{x}$ の值を $I_{0}$ および $m_{0}$ として

$$
\xi=x / L, \quad \eta=y^{\prime} / L, \quad q \xi=m_{x} / m_{0}, \quad i \xi=I_{x} / I_{0}
$$

と拈けば（2）は

$$
\begin{array}{ll} 
& \frac{d^{2}}{d \xi^{2}}\left(i \xi \frac{d^{2} \eta}{d \xi^{2}}\right)-\Omega^{2} q \xi \eta=0 \\
& \Omega^{2}=\frac{m_{0} L^{4} \omega^{2}}{E I_{0} g}
\end{array}
$$

端末条件は $x=0$ 及び $x=L$ に拉いて $Q(x, t)=M(x, t)=0$ となり，ここに $Q$ および $M$ はそれぞれ船体 断面に㗢く剪断力および曲げモーメントであつて

$$
\begin{aligned}
& M(x, t)=-E I_{x} \frac{\partial y^{2}(x, t)}{\partial x^{2}}=-\frac{E I_{0}}{L} i \xi \frac{d^{2} \eta}{d \xi^{2}} \sin \omega t \\
& Q(x, t)=\frac{\partial M(x, t)}{\partial x}=-\frac{E I_{0}}{L^{2}}\left(i \xi \frac{d^{3} \eta}{d \xi^{3}}+\frac{d i \xi}{d \xi} \frac{d^{2} \eta}{d \xi^{2}}\right) \sin \omega t
\end{aligned}
$$

となるから，端末条件は次式で与えられる。

$$
\xi=0 \text { および } \xi=1 \text { に於て } \frac{d^{2} \eta}{d \xi^{2}}=0, \frac{d^{3} \eta}{d \xi^{3}}=0
$$

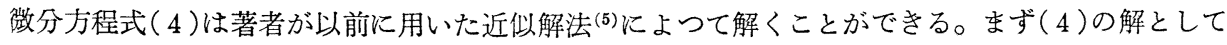

$$
\bar{\eta}=C_{0} \eta_{0}+C_{1} \eta_{1}+C_{2} \eta_{2}+C_{3} \eta_{3}+\cdots \cdots+C_{n} \eta_{n}=\sum_{i=0}^{n} C_{i} \eta_{i}
$$

と拈き，各項の函数として

$$
\begin{gathered}
\eta_{0}=1, \quad \eta_{1}=\xi-\frac{1}{2}, \\
\eta_{i}=\alpha_{i}\left(\sin s_{i} \xi+\sinh s_{i} \xi\right)+\cos s_{i} \xi+\cosh s_{i} \xi \\
\text { ここに } \alpha_{i}=\frac{\sin s_{i}+\sinh s_{i}}{\cos s_{i}-\cosh s_{i}}=\frac{\cos s_{i}-\cosh s_{i}}{\sinh s_{i}-\sin s_{i}} \\
(i=2,3, \cdots \cdots, n)
\end{gathered}
$$

を採用する。 $\eta_{i}$ は剪断の影響を無視した場合の両端自由一様断面梁の normal 函数であつて ${ }^{(6)}, \bar{\eta}$ は端末条件

Table $1 s_{i}$ および $\alpha_{i}$

\begin{tabular}{|c|c|c|c|c|c|}
\hline$i$ & $z$ & 3 & 4 & 5 & 6 \\
\hline$s_{i}$ & 4.7300407 & 7.8532046 & 10.995608 & 14.137165 & 17.278760 \\
$\alpha_{i}$ & -0.9825022 & -1.0007773 & -0.9999665 & -1.0000015 & -0.9999999 \\
\hline
\end{tabular}

(8)を完全に満足する。尚 $s_{i}$ は $\cos s \cosh$ $s=1$ の根であつて, $i=2,3,4,5,6$ に対 する $s_{i}$ および $\alpha_{i}$ は Table 1 に示すごと き值となる。

さて $\bar{\eta}$ の各項の係数 $C_{\imath}$ を定めるため

Galerkin 法(7)を用いると次の $n+1$ 個の条件式が得られる。

$$
\int_{0}^{1}\left[\frac{d^{2}}{d \xi^{2}}\left(i \xi \frac{d^{2 \eta}}{d \xi^{2}}\right)-\Omega^{2} q \bar{\xi} \bar{\eta}\right] \eta_{i} d \xi=0 \quad(i=0,1,2, \cdots \cdots, n)
$$

そこで（9）ょり

$$
\begin{gathered}
\frac{d^{2} \bar{\eta}}{d \xi^{2}}=\sum_{j=2}^{n} C_{j} s_{j}^{2} \zeta_{j} \\
\zeta_{j}=\alpha_{j}\left(-\sin s_{j} \xi+\sinh s_{j} \xi\right)-\cos s_{j} \xi+\cosh s_{j} \xi
\end{gathered}
$$

$$
\text { ここに }
$$

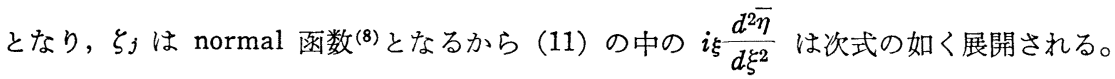




$$
i_{\xi} \frac{d^{2} \bar{\eta}}{d \xi^{2}}=\sum_{j=2}^{n} C_{j} s_{j}^{2} i \xi_{\xi} \zeta_{j} \equiv \sum_{j=2}^{n} K_{j} \zeta_{j}
$$

ここに $K_{j}$ 治次のよ5にして定められる定数である。即ち

$$
\int_{0}^{1} \eta_{j^{2}} d \xi=\int_{0}^{1} \zeta_{j}^{2} d \xi=1, \int_{0}^{1} \eta_{j} \eta_{m} d \xi=\int_{0}^{1} \zeta_{j} \zeta_{m} d \xi=0 \quad(j \neq m)
$$

となることを用いると， $K_{j}$ は次の如くになる。

$$
K_{j}=\frac{1}{\int_{0}^{1} \zeta_{j}^{2} d \xi} \sum_{m=2}^{n} C_{m} s_{m}^{2} \int_{0}^{1} i \xi_{\zeta j} \zeta_{m} d \xi=\sum_{m=2}^{n} C_{m} s_{m}^{2} \alpha_{j m} \quad(j=2,3, \cdots \cdots, n)
$$

ただしここに $\quad \alpha_{j m}=\alpha_{m j}=\int_{0}^{1} i \xi \zeta_{j} \zeta_{m} d \xi(j, m=2,3, \cdots \cdots, n)$

したがつて（16）を（14）に代入して

$$
i \xi \frac{d^{2} \bar{\eta}}{d \xi^{2}}=\sum_{j=2}^{n} \sum_{m=2}^{n} C_{m} s_{m}^{2} \alpha_{j m} \zeta_{j} \quad \text { (18) } \quad \therefore \quad \frac{d^{2}}{d \xi^{2}}\left(i \frac{d^{2} \eta}{d \xi^{2}}\right)=\sum_{j=2}^{n} \sum_{m=2}^{n} C_{m} s_{m}^{2} S_{j}^{2} \alpha_{j m} \eta_{j}
$$

が得られ，ここに $\eta_{j}$ は既に（10）によつて与六たものである。

さて（9）执よび（19）を（11）に代入すると

$$
\int_{0}^{1}\left[\sum_{j=2}^{n} \sum_{m=2}^{n} C_{m} s_{m}^{2} s_{j}^{2} \alpha_{j m} \eta_{j}-\Omega^{2} q \xi\left\{C_{0}+C_{1} \eta_{1}+\sum_{m=2}^{n} C_{m} \eta_{m}\right\}\right] \eta_{i} d \xi=0 \quad(i=0,1,2, \cdots \cdots, n)
$$

そこで今（20）に新ける定積分の項をそれぞれ

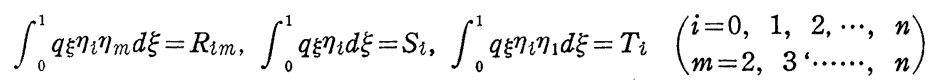

と执さ，(15）の関係を考虑に入れると（20）は結局次式の形で表わされる。

$$
\left.\begin{array}{ll}
i=0,1 \text { の時 } & \sum_{m=2}^{n} C_{m} R_{i m}+C_{0} S_{i}+C_{1} T_{i}=0 \\
2 \leqq i \leqq n \text { の時 } & \sum_{m=2}^{n} C_{m}\left(s_{m}^{2} s_{i}{ }^{2} \alpha_{i m}-\Omega^{2} R_{i m}\right)-\Omega^{2} C_{0} S_{i}-\Omega^{2} C_{1} T_{i}=0
\end{array}\right\}
$$

これが振動数方程式に相当するものであつて，これより $2,3, \cdots \cdots, n$ 節振動の固有値 $\Omega$ が求められ，それ ぞれの $\Omega$ に対応して $(9)$ に含まれる各項の係数 $C_{i}$ の間の関係が定まり, 各節振動の撓み曲線の形が求めら れる。

\section{§2. 船体撓み振動の実用的解法}

普通の貨物船において, その固有振動数のみを求める場合には, 次のごとき考察によつて前節の計算法をかなり

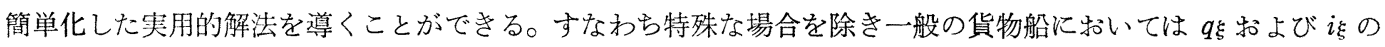

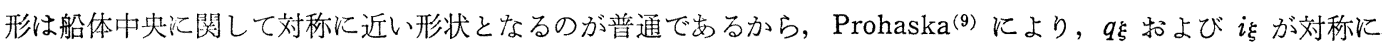
近い場合はその前後半部の平均を採つて対称分布におきかえても結果に扣よぼす影響はほとんど無視できる程度 のものとなる。

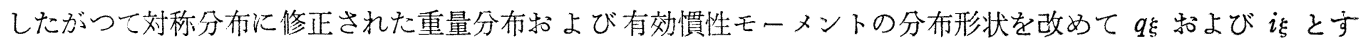
ると前述の $\alpha_{i m}, R_{i m}, S_{i}, T_{i}$ は

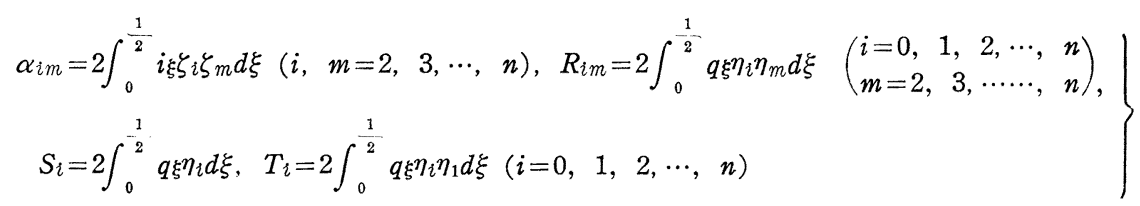

となり, 対称性より $S_{i}=0(i=1,3,5, \cdots), T_{i}=0(i=0,2,4,6, \cdots), \alpha_{i m}=R_{i m}=0$ ( $i+m$ が奇数の時 $)$ と なりまた振動数方程式(22)は $C_{0}$ 抽び $C_{1}$ を消去した形で次のように表わすことがでさる。

$$
\begin{array}{lr}
i=2,4,6, \cdots \text { の時 } & \sum_{m=2,4,6, \ldots}^{n} C_{m}\left[s_{m}{ }^{2} s_{i}{ }^{2} \alpha_{i m}-\Omega^{2}\left(R_{i m}-\frac{S_{i} R_{0 m}}{S_{0}}\right)\right]=0 \\
i=3,5,7, \ldots \text { の時 } & \sum_{m=3,5,7, \ldots}^{n} C_{m}\left[s_{m}{ }^{2} s_{i}{ }^{2} \alpha_{i m}-\Omega^{2}\left(R_{i m}-\frac{T_{i} R_{1 m}}{T_{1}}\right)\right]=0
\end{array}
$$




\begin{tabular}{|c|c|c|c|}
\hline & 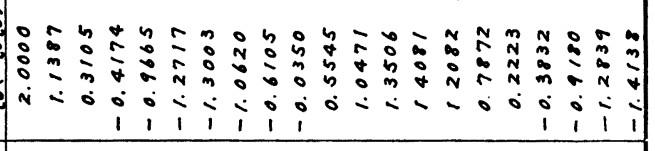 & $\underset{N}{*}$ & 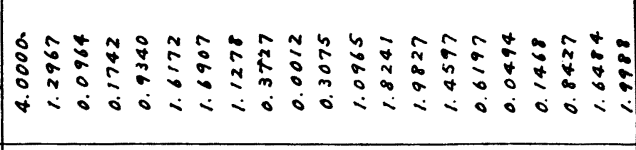 \\
\hline 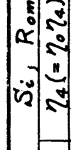 & 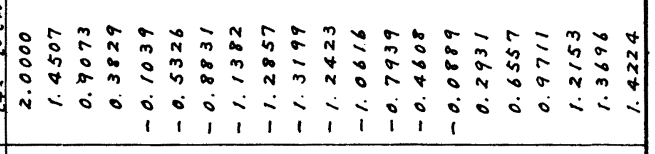 & స్ำ & 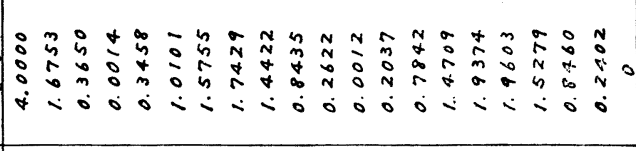 \\
\hline & 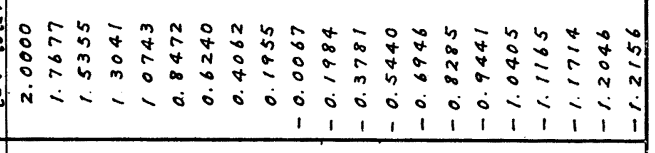 & 고 & 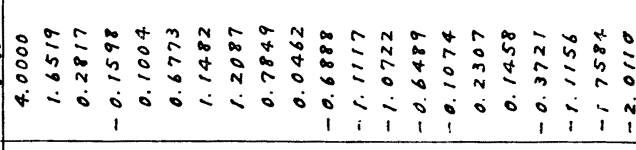 \\
\hline & 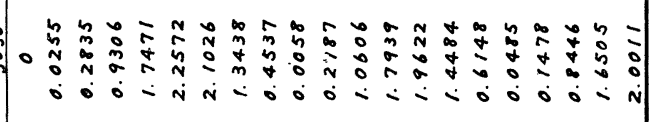 & & 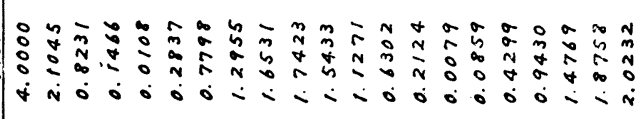 \\
\hline & 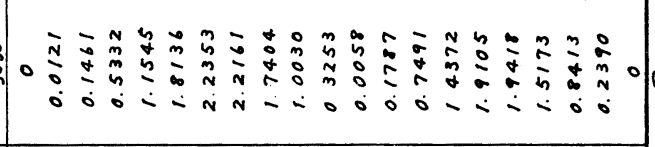 & & 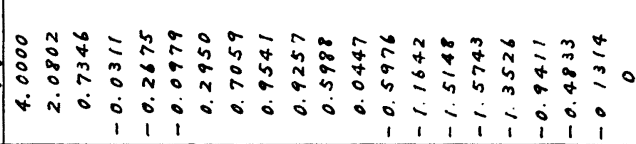 \\
\hline & 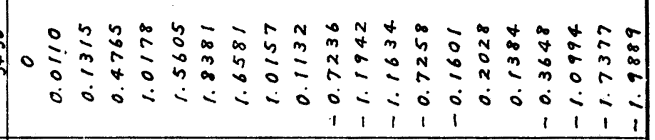 & & 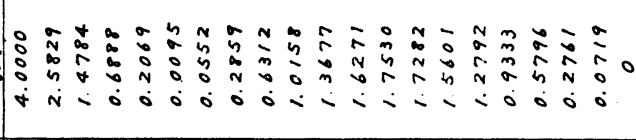 \\
\hline & 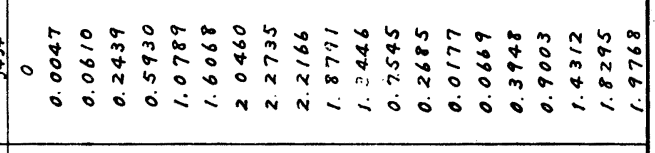 & $\approx$ & 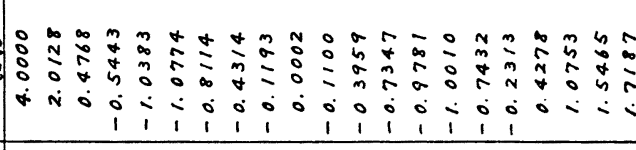 \\
\hline ช & 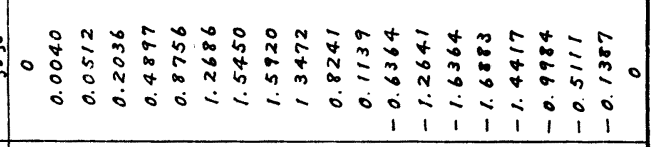 & & 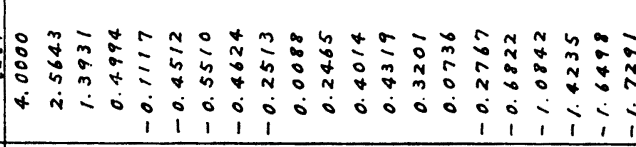 \\
\hline$\tilde{c}$ & 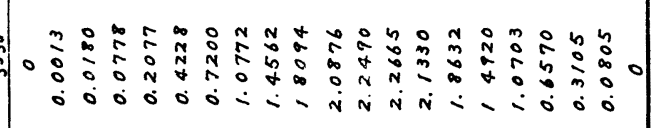 & $\approx$ & 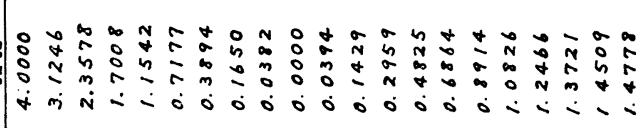 \\
\hline & 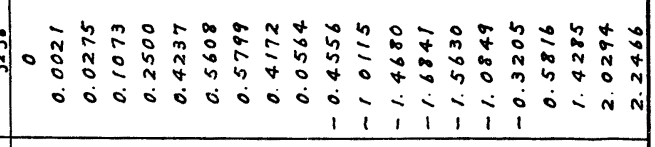 & s. & 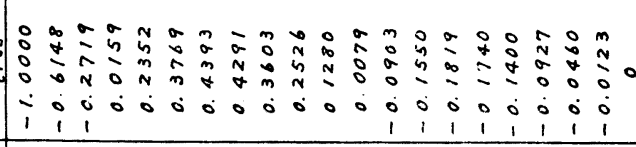 \\
\hline & 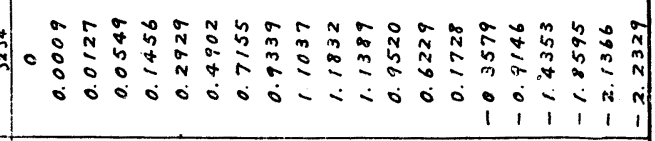 & & 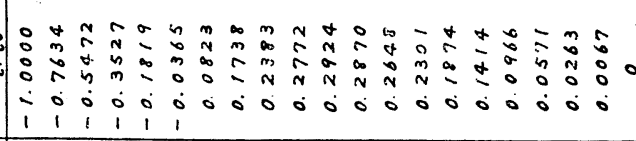 \\
\hline 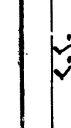 & 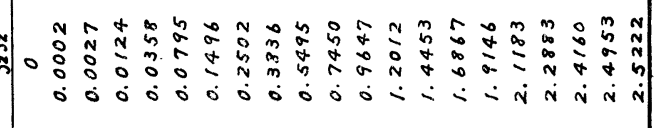 & $\approx$ & 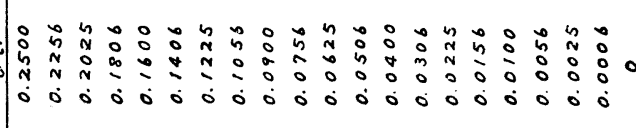 \\
\hline wes & 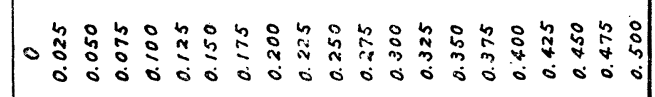 & $\operatorname{sen}$ & 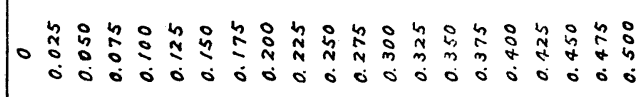 \\
\hline
\end{tabular}


（24）の第 1 式は偶数節振動, 第 2 式は奇数節振動に対するものである。これらより C が同時に 0 でない根 を有するための条件として係数行列式を 0 とおいた式を $\Omega^{2}$ に関して解けば固有值が求められる。 $\alpha_{i m}, R_{i m}$, $S_{i}$ 抢よび $T_{i}$ の計算は Simpson の公式による数值積分で求められる。 $\xi=0 \sim 0.5$ の間を 20 等分した各分点に 拉ける $\zeta_{i} \zeta_{m}, \eta_{i} \eta_{m}$ 等の函数值を Table 2 亿示す。

な招 4 節程度までの固有值を求めるには $\bar{\eta}$ は 7 項すなわち $n=6$ まで採れば精度は十分満足できるものとな

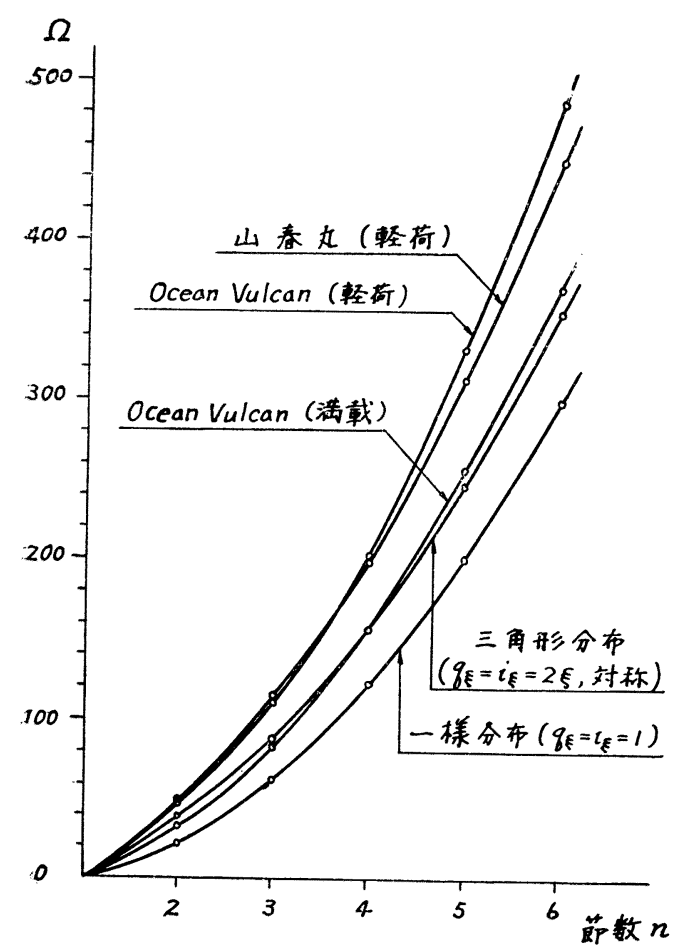

Fig. 1 貨物船における $\Omega$ の実例

り，2〜6 節に拉ける固有值の誤差は $0.02 \sim 0.2 \%$ で あつて実用的には十分正確である。2隻の貨物船山春 丸就よび s.s. Ocean Vulcan について上述の方法で 求めた $\Omega$ の值を Fig. 1 に示す。（§10 特よび § 11 参照)

§3. 剪断および回転慣性の影響を考慮に入れた船 体振動の固有值

一様断面梁の場合に剪断の影響を考慮すれば，基礎 方程式 (4) に相当する式は

$$
\begin{gathered}
\frac{d^{4} \eta}{d \xi^{4}}+\beta \Omega^{2} \frac{d^{2} \eta}{d \xi^{2}}-\Omega^{2} \eta=0 \\
\text { ここに } \beta=\frac{E I_{0}}{A_{0} G L^{2}}, \Omega^{2}=\frac{m_{0} L^{4} \omega^{2}}{E I_{0} g}
\end{gathered}
$$

となる(6)。ここで $A_{0}$ は剪断に対する有効断面積, $\beta$ は剪断の影響を示すパラメター， $\Omega$ は固有值であつ て, 両端自由の場合の振動数方程式は次式で与えられ る(6)。

$$
\left.\begin{array}{r}
\beta \Omega \sin p \sinh q+2(\cos p \cosh q-1)=0 \\
\text { こに } p=\sqrt{\frac{\beta \Omega^{2}}{2}+\sqrt{\left(\frac{\beta \Omega^{2}}{2}\right)^{2}+\Omega^{2}}} \\
q=\sqrt{-\frac{\beta \Omega^{2}}{2}+\sqrt{\left(\frac{\beta \Omega^{2}}{2}\right)^{2}+\Omega^{2}}}
\end{array}\right\}
$$

つぎに剪断扣よび回転慣性の影響を同時に考虑する

洔は基礎方程式は次式で与えられる(6)。

$$
\frac{d^{4} \eta}{d \xi^{4}}+\left\{\beta+\left(\frac{r}{L}\right)^{2}\right\} \Omega^{2} \frac{d^{2} \eta}{d \xi^{2}}-\Omega^{2}\left\{1-\left(\frac{r}{L}\right)^{2} \beta \Omega^{2}\right\} \eta=0
$$

ここに $r$ は所謂断面の回転半径を示す。(29) の左辺第 3 項の $\{\quad\}$ 内の $\left(\frac{r}{L}\right)^{2} \beta \Omega^{2}$ は普通の船体構造では 4 節 振動程度までならば 1 に比べて十分小となるのでこの項を無視すれば（29）は

$$
\begin{array}{ll} 
& \frac{d^{4} \eta}{d \xi^{4}}+\beta_{1} \Omega^{2} \frac{d^{2} \eta}{d \xi^{2}}-\Omega^{2} \eta=0 \\
\text { ただし } & \beta_{1}=\beta+\left(\frac{r}{L}\right)^{2}
\end{array}
$$

となり，(25) と同型の方程式となる。従つて剪断および回転慣性の影響そ同時に考虑した場合の結果は前の結果 において $\beta$ の代りに $\beta_{1}$ を用いることによつて直ちに求められる。

さて船体振動に対する剪断および回転慣性の影響については次のごとき考察によりその影響を算定する。後述 （§ 4）のごとく船体の場合は剪断に対する有効断面積は船の長さ方向には余り変化がなく近似的には一様と考学 ることがでさるから，船体中央断面と同一の断面を有し船体と同じ長さをもつ一様断面梁を考え，これの $\beta_{1} に$ 剂する固有值 $\Omega_{i}$ と剪断就よび回転慣性を無視した場合 $\left(\beta_{1}=0\right)$ の固有值 $\bar{\Omega}_{i}$ との比 $c_{i}=\Omega_{i} / \bar{\Omega}_{i}(i=2,3,4)$ を求め, この $c_{i}$ を船体振動の固有值に対する修正係数とする。普通の貨物船では $\beta_{1}$ の值は 0.01 前後の值と なる。 $\beta_{1}=0.005 \sim 0.02$ の範囲で 2 4 節振動に対して（27）によつて $c_{i}$ を求めると Fig. 2 のごとくになる。 従つて船体撓み振動の固有值は前節の方法で得た $\Omega_{i}$ を修正して $c_{i} \Omega_{i}$ として与えられる。な拉記の $\beta_{1}$ を以 


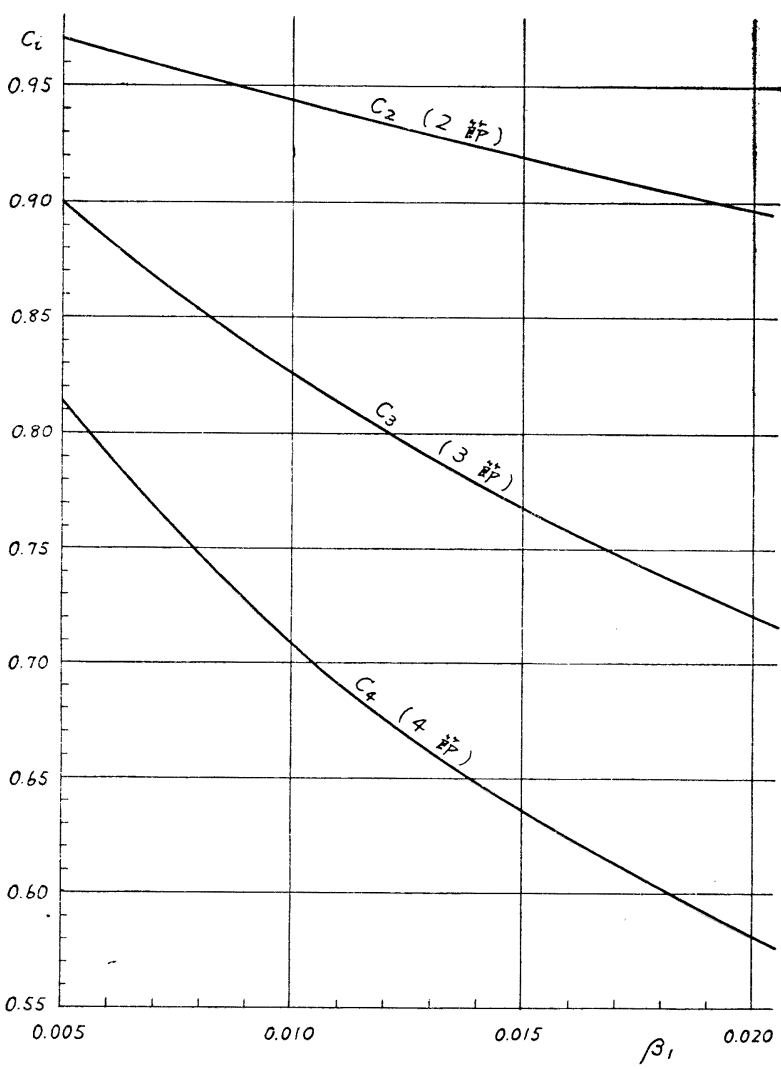

Fig. 2 固有値修正係数 $c_{i}$

後相当剪断係数と呼ぶ。

§ 4. 重量分布 $q_{\xi}$, 有効慣性モーメント分 布 $\boldsymbol{i} \xi$ および相当剪断係数 $\beta_{1}$ について

（1）重量分布 $g_{\xi}$

排水量 $\Delta$ に相当する重量の分布は従来の 方法で求める。付加水質量は振動の次数によ つて変化し，従つて（2）に含まれる $m_{x}$ は 各節振動において変化する。しかしながら固 有值に関係するのは $m_{x}$ の分布形状即ち $q \xi$ で岕り，また特殊な載貨状態を除いては船体 重量 $\Delta$ の分布形状と付加水質量の分布形状 とは比較的似かよつた形となるから，2４ 節振動の範囲では付加水質量の絶対值が多少 変化しても $q \xi$ には余り影響はない。従つて ここでは $q \xi$ は $2 \sim 4$ 節振動で同一のものを 用い次のよ5に定める。すなわら船体重 量 $\Delta$ と 2 次元運動として求めた付加水質量 $\Delta^{\prime}$ の合計重量 $\Delta+\Delta^{\prime}$ の分布より $q \xi$ を定め

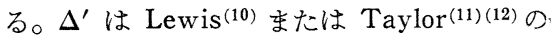
方法によつて求められる。

（2）船体の有効断面慣性モーメント㧤よ びその分布 $i \xi$

船体の断面慣性モーメントの算定は縦強度 計算の場合に準じて行なう。な怙有振動数 $N$ の算定には曲げ剛性 $E I$ の形で現われる

が， $E$ の值は構造用鋼材の標準の值 $E=2.1 \times 10^{7} \mathrm{t} / \mathrm{m}^{2}$ を用いる。

遮浪甲板型または平甲板型の貨物船の場合は上記の計算基準により直ちに船体各断面の断面慣性モーメント $I_{x}$ が求められる。ただし甲板室はほとんぞ有効には効かないから, 強力甲板以下について求めた $I_{z}$ を有効慣 性モーメントとする。

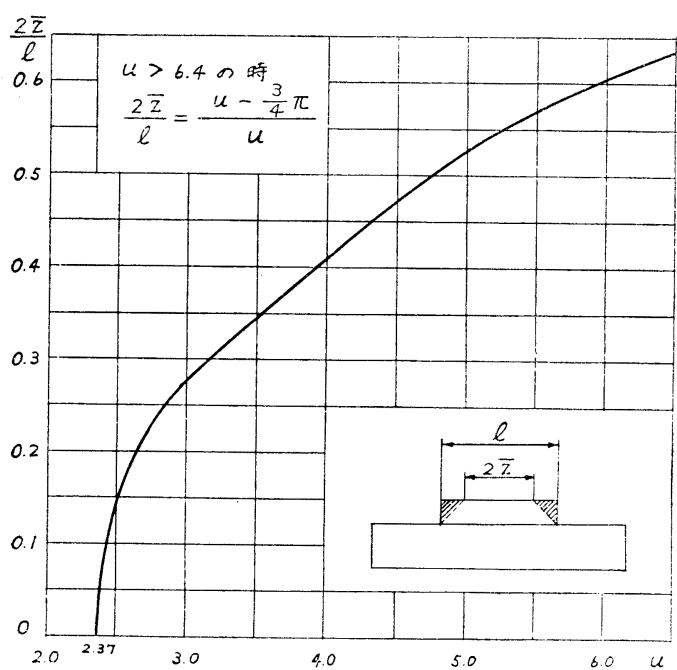

Fig. 3 船楼が完全に有効に働く長さの範囲 $2 \bar{z} / l$
三島型貨物船の場合には船楼の効果を考虑した有 効慣性モーメント $I_{x}$ を求める必要がある。船楼の 影響については振動時の船体の曲げモーメント分布 を仮定し，Bleich (13) の理論を適用して船楼の有効 性を調べた結果，2〜4 節振動の範囲内では断面有 効曲げ剛性は振動の次数によつてほとんど変らない ことが判つたので(14)，これらの結果より有効断面 慣性モーメントの算定法として付録 1 に示す方法を 得た。これの適用法を要約すると船楼の長さ $l$, 船 楼と主構造の間のバネ定数 $K$, 船楼扣よび主構造を それぞれ単独の梁とみなしたときの各々の断面慣性 モーメント $I_{1}, I_{2}$, 中性軸の位置を示す係数 $\alpha_{1}$, $\alpha_{2}$ 扣よび係数 $\mu$ （以上付録 1 参照）扣よび弾性係 数 $E$ によつて定まる量

$$
u=-\frac{l}{2} \sqrt[4]{\frac{K}{4 E}} \quad \begin{gathered}
1+\mu \\
\alpha_{2} I_{1}+\mu \alpha_{1} I_{2}
\end{gathered}
$$

が求まると Fig. 3によつて船楼が完全に有効に(す 
なわち主構造と一体の梁として）働く長さの範囲 $2 \bar{z} / l$ が求められる。この範囲から外側では船楼端に向つて有 効慣性モーメントは减少し主構造の $I_{2}$ の值に連続する。

な挆船楼甲板上の甲板室は普通の貨物船ではその有効性が非常に小さいことが確かめられたので(14), 断面慣性 モーメントには甲板室は考慮に入れない。以上により船体各断面の有效慣性モーメントが得られると，(3)によ つて $i_{\xi}$ が定まる。

(3) 相当剪断係数 $\beta_{1}$

(a) 剪断败対する有効断面積 $A_{0}$

（26）に示した $\beta$ を求めるには剪断に対する有効断面積 $A_{0}$ を求める必要がある。熊井教授(1), Johnson ${ }^{(2)}$ 等 によれば普通の船体構造では垂直撓み振動の場合には剪断に対する有効断面積は船の長さ方向に略々一定と考兄 てよい。著者に执いても 2,3 の実船につき $A_{0}$ の分布を調べた結果同様な結論を得たので(15)，これらの結果を 実船汇適用できる形にまとめると貨物船の場合 $A_{0}$ は次の略算法で求められる。すなわち船体中央断面に括いて

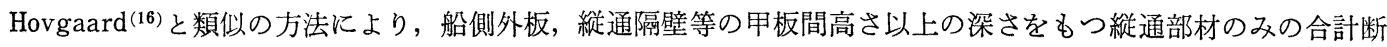
面積 $A_{v}$ を以て $A_{0}=A_{v}$ とすれば実用上十分よい近似值が得られる。

したがつて遮浪甲板型拉よび平甲板型貨物船並に短い船楼をるつ三島型貨物船では上甲板以下の断面について 上述の $A_{v}$ を求めて $A_{0}=A_{v}$ とすればよい。長船橋楼（ $0.4 \mathrm{~L}$ 程度）をもつ三島型貨物船の場合は船楼が曲げに 対して有効に働く長さがかなり大となるので， $A_{0}$ の值としては上甲板以下を考皃たときの $A_{v}$ と船橋楼甲板以 下を考えたときの $A_{v}$ の平均值を採つてこれを $A_{0}$ とすればよい。

(b) 回転 慣 性

(31) に示した $(r / L)^{2}$ の值を求めるには船体断面の回転半径 $r$ を求める必要がある。船体中央断面に打ける 船の長さ方向単位長さ当りの船体重量を $m_{0}{ }^{\prime}$ とし, 曲げの中性軸まわりの重量慣性モーメントを $J_{0}$ とすると $r^{2}=J_{0} / m_{0}^{\prime}$

そなる。 $(r / L)^{2}$ の大きさは普通の貨物船では $\beta$ の約 $1 / 10$ 程度の值となる。

以上に上り相当剪断係数は $\beta_{1}=\beta+(r / L)^{2}$ として与兄られる。

\section{II. 付加水質量および船体固有振動数}

\section{§5. 船底の強制振動}

船体の付加水質量は Lewis ${ }^{(10)}$ 又は Taylor ${ }^{(11)(12)}$ の方法によつて求められ，2節振動ではこれによつて船体 固有振動数が可成正確汇算定される。しかし 3 節以上ではこれらの方法による付加水質量では, Richards ${ }^{(3)}$ む 述べているように固有振動数の実測值と計算値の間に可成の差を生じ, 計算值は常に実測值より大となる。この ような誤差の生ずる原因に対する 1 つの説明として，垂直撓み振動の際船底が強制振動を受けることを考虑に入 れると船底部が水に与える運動エネルギーが従来の計算值より大となり，見掛け上付加水質量が增加するとして 説明される。

船底の振動は厳密には平面格子構造として考劣るべさであるが，ここでは簡単のため船底構造を横方向に切出 した単位幅を持つ 1 つの梁に怙きか兄，これを以後船底相当梁と呼び，その曲げ剛性 $E I_{e}$ は後述（§ 8) の方法 によつて算定する。

今, 相当梁を一様断面で両端単純支持と考光*, 端末で $y \sin \omega t$ なる強制 変位を受けるとすれば，運動方程式は Fig. 4 亿示すよ5 亿梁と共慟く座 標系 $x, y_{1}$ について次のごとく与兄らる。すなわち相当梁の断面慣性モ 一メントを $I_{e}$, 付加水質量を含めた梁の単位長さ当りの重量を $m$, 梁と共に 動く座標系飞対する梁の獟及を $y_{1}$ とし，簡単のため減衰を無視するときは

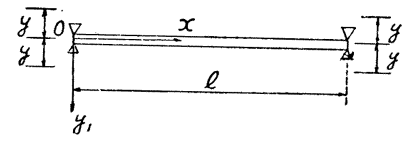

Fig. 4

$$
E I_{e} \frac{\partial^{4} y_{1}}{\partial x^{4}}+\frac{m}{g} \frac{\partial^{2} y_{1}}{\partial t^{2}}=\frac{y m}{g} \omega^{2} \sin \omega t
$$

となる。ここに y は端末に抢ける強制変位の片振幅， $\omega$ はその円振動数でこれらは船体振動の片振幅および円 振動数に等しい。強制振動を考㝋今 $y_{1}(x, t)=y_{1}(x) \sin \omega t$ と括けば (34) は

* 普通の横助骨方式の貨物船の横強度より類推して, 船底部を両端支持梁とみなすことは実用的には差し支 壳ないるのと考光られる。 


$$
\frac{d^{4} y_{1}}{d x^{4}}-\beta^{4} y_{1}=\beta^{4} y \quad(35) \quad \text { ここ } \quad \beta^{4}=\frac{m \omega^{2}}{E I_{e} g}
$$

となり（35）の一般解は次式の如くになる。

$$
y_{1}=A \sin \beta x+B \cos \beta x+C \sinh \beta x+D \cosh \beta x-y
$$

端末条件として $x=0$ および $x=l$ において $y_{1}=d^{2} y_{1} / d x^{2}=0$ とすれば相当梁の振動撓み曲線 $y_{1}$ は

$$
y_{1}(x, t)=\frac{y}{2}\left[\frac{1-\cos \beta l}{\sin \beta l} \sin \beta x+\cos \beta x+\frac{1-\cosh \beta l}{\sinh \beta l} \sinh \beta x+\cosh \beta x-2\right] \sin \omega t
$$

これより相当梁の振動速度 $v_{1}(x, t)=\partial y_{1}(x, t) / \partial t$ は

$$
v_{1}(x, t)=\frac{y \omega}{2}\left[\frac{1-\cos \beta l}{\sin \beta l} \sin \beta x+\cos \beta x+\frac{1-\cosh \beta l}{\sinh \beta l} \sinh \beta x+\cosh \beta x-2\right] \cos \omega t
$$

となる。 $\beta l$ がこの梁の固有值 $\beta_{0} l=n \pi(n=1,2,3, \cdots)$ に等しくなるとき共振の状態となる。

\section{§ 6. 船底の強制振動が船体の付加水質量におよぼす影響}

船体が垂直撓み振動をするとき，船底相当梁の振動速度は船体の振動速度 $v=\partial y / \partial t$ より（39）による $v_{1} な$ る量だけ大となり $v+v_{1}$ となる。 $v+v_{1}$ は相当梁の長さ方向に変化するが，水の持つ運動エネルギーは与えられ た速度の 2 乗に比例することにより，次のごとき簡単化すなわち相当梁の撓み振動をこれと等しい運動エネルギ 一を持つような並進振動に拈きかえて考学るとができる。その並進振動の速度 $\bar{v} は$

$$
\bar{v}^{2}=\frac{1}{l} \int_{0}^{l}\left(v+v_{1}\right)^{2} d x
$$

を満足するものとなり，従つて水に与える運動エネルギーの点では両者は近似的に等価とみなし得る。ゆえに (39) により速度の最大振幅について考觉ると

$$
v+v_{1}=\frac{y \omega}{2}\left[\frac{1-\cos \beta l}{\sin \beta l} \sin \beta x+\cos \beta x+\frac{1-\cosh \beta l}{\sinh \beta l} \sinh \beta x+\cosh \beta x\right]
$$

であるから，(41）を（40）に代入し，且つ $y \omega=v$ を考慮すると $\bar{v}^{2}$ は次式のごとくになる。

$$
\bar{v}^{2}=\frac{v^{2}}{4 \beta l \sin ^{2} \beta l \sinh ^{2} \beta l}\left\{(1-\cos \beta l)(\beta l+3 \sin \beta l) \sinh ^{2} \beta l+(\cosh \beta l-1)(\beta l+3 \sinh \beta l) \sin ^{2} \beta l\right\}
$$

ここで今 $\bar{v} / v=K$ とおき，船底の振動速度を $\bar{v}=K v$ とすれば，水の運動エネルギーはその殆んど大部分が船底 の flat な部分から与えられる速度によると考えてもよいから，周困の水の持つ実際の運動エネルギーは従来の 如く船体の振動速度 $v$ に対して求めたものの $K^{2}$ 倍となる。 $K^{2}$ は (42) により次式で与えられる。

$$
K^{2}=\frac{(1-\cos \beta l)(\beta l+3 \sin \beta l) \sinh ^{2} \beta l+(\cosh \beta l-1)(\beta l+3 \sinh \beta l) \sin ^{2} \beta l}{4 \beta l \sin ^{2} \beta l \sinh ^{2} \beta l}
$$

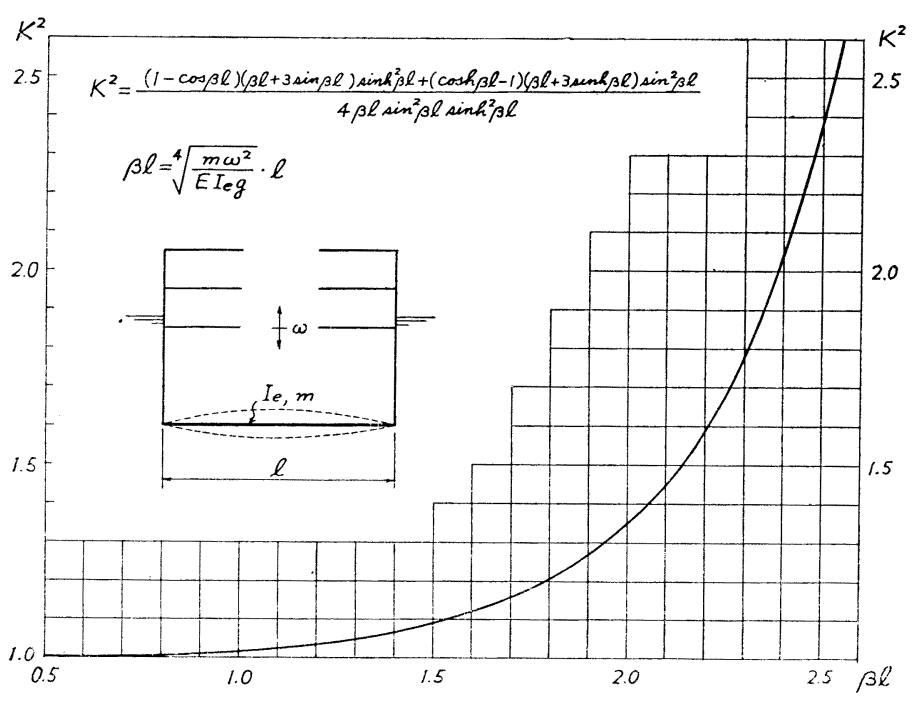

Fig. $5 K^{2}$ の值（付加水質量修正倸数）
したがつて船体の付加水質量は従 来の計算值の $K^{2}$ 倍となる。(43) により $K^{2}$ の值を $\beta l$ の变化に対 して求めたものを Fig. 5 に示す。

§7. 船体の付加水㬏量および 固有振動数の算定

船体垂直撓み振動の付加水質量 はまず，すでに求めた 2 次元運動 と考えた場合の $\Delta^{\prime} に 3$ 次元運動 修正係数 $J$ を掛ける。 $J$ の值は Lewis $^{(10)}$ によるものでは撓み振 動をする梁の断面がその中性軸凨 りに回祘することによる影響足無 視して求められているので，その 影響の程度を調べるため Lewis の取扱つた回転楕訛体の場合につ き上述の断面の回転をも考虑し 


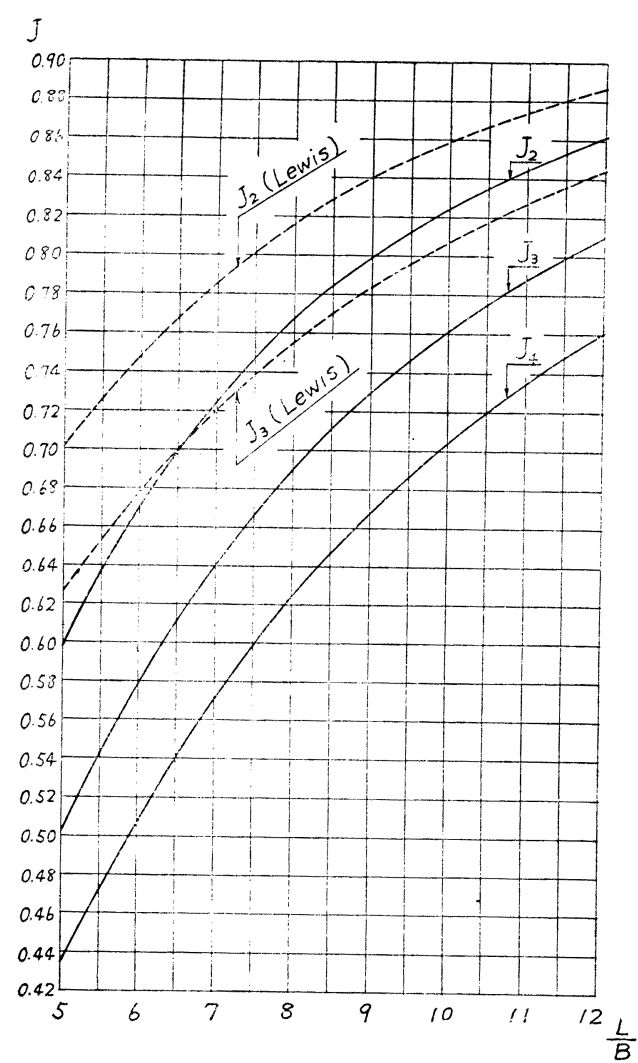

Fig. 63 次元運動修正係数 $J$
て $J$ の值を求めた結果， $J$ の值は Fig. 6 のごとく Lewis の值より幾分小さくなる。（付録 2 参照）

つぎに(43)の形からわかるように $K^{2}$ は $\beta l$ 従つて $\omega$ の函数で㤩る。しかるに $\omega$ は船体固有円振動数である から

$$
\omega=\frac{c \Omega}{L^{2}} \sqrt{\frac{E I_{0} g}{m_{0}}}\left(\sec ^{-1}\right)
$$

であり，また排水量 $\Delta$ と実際の付加水質量 $K^{2} J \Delta^{\prime}$ と の合計重量 $\Delta_{1}$ と $m_{0}$ の関係は次のごとくである。

$$
\Delta_{1}=\Delta+K^{2} J \Delta^{\prime} \quad(45), \quad \Delta_{1}=m_{0} L S_{0}
$$

ここに $S_{0}$ は (23) によつて与えられたもので $\Delta_{1}$ の分 布形状 $q \xi$ によつて定まる定数である。(44), (45), (46) より $m_{0}$ 执よび $\Delta_{1}$ を消去すると

$$
K^{2}=\frac{1}{J \Delta^{\prime}}\left\{\frac{E I_{0} g S_{0}(c \Omega)^{2}}{L^{3} \omega^{2}}-\Delta\right\}
$$

が得られ，(43）と（47）を連立方程式として $K^{2}$ 及び $\omega$ が求められる。これより船体の付加水質量は $K^{2} J \Delta^{\prime}$ として，また船体固有振動数は $N=60 \omega / 2 \pi(\mathrm{c} / \mathrm{min})$ と して求められる。

実際の計算に当つては（43）と（47）の連立方程式は 図式解法による。即ち後述の方法 (§8) によつて相当梁 の $I_{e}$ と $m$ の值が定まると (36) により $\beta l$ が $\omega$ のみ の函数となるから，Fig. 5 を用いて船底相当梁に対す る $K^{2}-\omega$ 曲線が得られ，一方船体振動の方は 2 節, 3 節, ……対する固有值 $c \Omega$ と $J$ の值を用いて (47) に

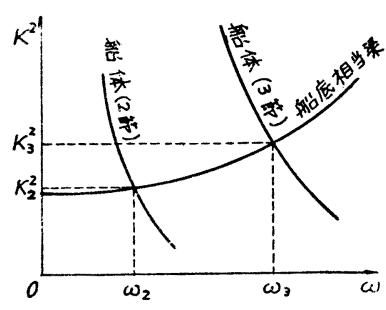

Fig. 7 より各節に対する $K^{2}-\omega$ 曲線が得られて Fig. 7 のごとくになる。従つて 求める $K^{2}$ 抢よび $\omega$ の值はこれらの曲線の交点の座標として与えられる。

な打上述の方法は船底相当梁の強制振動を減衰を無視して取扱つているの で， $\omega$ の值が相当梁の固有円振動数に近くなると実際とはかなり異なるので このような範囲では使用でさない。実船につきこの方法を適用すると Fig. 5 に拈いて $K^{2}<2.5$ の範曲では十分実用に供し得る。

\section{§ 8. 船底相当梁の $\boldsymbol{I}_{e}$ および $\boldsymbol{m}$ の算定}

横肋骨方式の場合はFig. 8 のごとく船奃構造は船側で単純支持, 横隔壁で 固定の平面格子棈造とみなされる。周辺で一様な強制变位 $y \sin \omega t$ を 受ける格子構造の撓又曲面の形状はその格子面に一様分布荷重を受け る時の静的な撓又曲面の形状と略々相似であると考觉，この平面格子 構造の棡性を算定するため，単位面積当り $q$ なる一様分布荷重を受 ける場合の静的な撓みを Schilling(17)の方法で求め付録 3 に示すごと き結果觉得心。

Fig. 8 に抢いて $l=$ 船の型幅, $l_{1}=$ 横隔壁間の距離とし，横部材は 平均断面慣性エーメント $I_{f}$ のものが等間隔（胁骨心距） $e$ に配置さ れるものとし，繸部材は centre girder 执よび side grider の断面慣

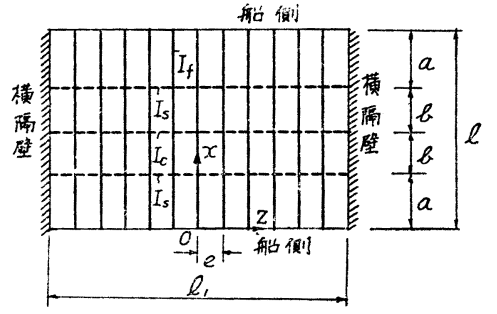

Fig. 8 性モーメントを夫々 $I_{C}$ 抢よび $I_{S}$ とする。な後述の実船の解析においては船底外板括よび内底板は完全以有 効に爋くとみなして， $I_{f}, I_{c}, I_{S}$ の算定には心距の 1.1 倍の有效幅を考虑に入れている。

さて $I_{f}$ なる断面慣性モーメントを持つ単独梁が両端支持で等分布荷重 $w=q e$ を受计るときの中央 $(x=l / 2)$ の撓みを $\eta^{(e)}$ とすれば, centre girder の撓み $y_{c}(z)$ は付録 3 の結果を記号的に表わして次のごとくになる。 


$$
y_{c}=\alpha(z) \eta^{(c)}
$$

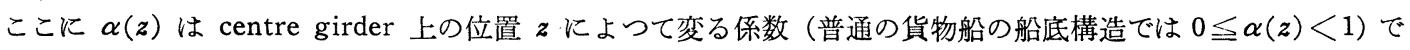
ある。一方, 横方向に平行に配置された多数の単独梁群を考え同じ荷重条件に対して各単独梁の最大撓みがそれ ぞれの位置での $y_{c}$ に等しくなるようにすればこの平行梁群によつて格子構造の撓みが近似的に表わされる。そ の時各単独梁の持つベき断面慣性モーメント $I_{z}$ は次式のごとくになる。

$$
I_{z}=I_{J} / \alpha(z)
$$

さて前述の船底相当梁を（49）の中から選ぶのであるが，それにはミ6において行なつたよ5に皮の持つ運動 エネルギーは与只られた速度の 2 乗に比例することを考慮すれば，上のごとく置きかえた平行単独梁の中から， それらの平均運動エネルギーに等しい運動エネルギーを持つような梁を採つて船底相当梁とすることができる。 このような条件を満たす単独梁を見出すには centre girder 上での $y_{c}$ の 2 乗平均を求める必要があるが，ここ では簡単のため, $y_{c}$ の最大值 $y_{c \max }$ と $y_{c}$ の平均值 $\bar{y}_{c}$ を求めて拈き, その最大撓みが $y_{c \mathrm{max}}$ と $\bar{y}_{c}$ の平均 值に等しくなるよ5な単独梁を以て船底相当梁と考えることにする*。従つてその最大撓みが夫ふ $y_{c \mathrm{max}}$ 拈よび $\bar{y}_{c}$ に等しい単独梁の断面慣性モーメントを $I_{\min }$ 执よび $\bar{I}$ とすると（48）により $y_{c \max }=\alpha_{\max } \eta(c)$ 及び $\bar{y}_{c}=$ $\bar{\alpha} \eta(c)$ となり, (49) によつて $I_{\min }=I_{\digamma} / \alpha_{\max }, \bar{I}=I_{\digamma} / \alpha$ となるから, 求める単独梁の $I$ は両者の平均を採つて

$$
I=\frac{1}{2}\left(I_{\min }+\bar{I}\right)=\frac{1}{2}\left(\frac{1}{\alpha_{\max }}+\frac{1}{\alpha}\right) I_{J}
$$

となる。§ 5 で取扱つた相当梁は単位幅の梁であるから，船底相当梁の断面慣性モーメント $I_{e}$ は次式のごと にくになる。

$$
I_{e}=\frac{I}{e}=\frac{1}{2}\left(\frac{1}{\alpha_{\max }}+\frac{1}{\alpha}\right)-\frac{I_{\jmath}}{e}
$$

な打上式中の $\alpha_{\max }$ 和よび $\bar{\alpha}$ の值は付録 3 により求められる。

一方格子構造としての船底の固有振動数を調ベるため, 奥田, 有馬両氏(18) ${ }^{(18)}$ る防撓材付矩形板の固有振動 数の算定式が適用でさるものとしてこれによつて求めた船底の固有振動数と, 上述の船底相当梁の固有振動数と を実船の場合について比較した結果両者が略々一致することが確かめられ，船底構造を相当梁におきかえた近似 理論の成立つことが確かめられた。 $L=130 \mathrm{~m}$ 前後の普通の貨物船では船底の固有振動数は付加水質量を考虑に 入れて $N=300 \mathrm{c} / \mathrm{min}$ 前後の值となる。

つぎに船底の振動に対する付加水質量は鬼頭氏 ${ }^{(19)}$ の方法を応用して付録 4 に示すごとくになる。その結果よ り相当梁の全長 $l$ に対する付加水質量 $M_{1}{ }^{\prime}$ は次式によつて与えられる。

$$
M_{1}^{\prime}=2.8677 \rho l^{2} \sum_{n=1}^{16} \frac{a_{n}^{2}}{\sqrt{n+9\left(\frac{l}{l_{1}}\right)^{2}}}
$$

ここに $l$ =船の型幅, $l_{1}$ =横隔壁間の距離, $\rho=$ 流体の密度であつて $a_{n}{ }^{2}$ は Table 3 に示す係数である。船底部 の鋼材重量より相当梁の自重 $W_{1}$, バラスト, 載貨のある場合は夫々の重量 $W_{2}, W_{3}, \cdots \cdots$ 等を求め, $M_{1}^{\prime}$ 及び

Table $3 a_{n}^{2}$ の值

\begin{tabular}{rl|c|c|c|c|c|c|}
\hline$n$ & 1 & 3 & 5 & 7 & 11 & 13 \\
\hline$a_{n}^{2}$ & 0.1710 & 0.1111 & 0.0428 & 0.0068 & 0.0009 & 0.0004 \\
\hline
\end{tabular}

これらの合計より相当梁の単位長さ当りの見掛けの重量 $m$ が求められる。

\section{III. 実船における解析例}

\section{§9. 解析を行なつた実船の要目}

解析を行なつた 2 隻の貨物船の主要項目括よび試験時の状態を Table 4 に示す。山春丸は G. T. $7150 t$ 型の 長船橋楼を有する三島型貨物船でめつて日立造船技術研究所広渡氏の御厚意により本船の解析に必要な資料が提

* (36) に与えたよ5に $\beta$ は $\sqrt[4]{I_{e}}$ に逆比例するから, $I_{e}$ の值の少々の変化によつて $\beta$ の值はほとんど変化 しないので，上述のことく相当梁の $I_{e}$ の算定に幾分荒い近似を用いてもその影響は極めて小さい。 
Table 4 船体主要項目および試験時の状態

\begin{tabular}{|c|c|c|c|c|c|c|}
\hline \multirow{2}{*}{ 船 名 } & \multicolumn{2}{|c|}{ 主 } & \multicolumn{2}{|l|}{ 項 } & \multicolumn{2}{|c|}{ 誄歌时の伏焦 } \\
\hline & 全長 L & 重總向長 $L_{B P}$ & 型巾 B & 型深 D & 吃水d & 排水量 $\Delta$ \\
\hline 山恭 丸(短荷) & $143.28 \mathrm{~m}$ & $134.00 \mathrm{~m}$ & $18.00 \mathrm{~m}$ & $10.50 \mathrm{~m}$ & $3.57 \mathrm{~m}$ & $5804 t$ \\
\hline Ocean Vulcan (㪍荷) & $134.569 \mathrm{~m}$ & $126.797 \mathrm{~m}$ & $17.342 \mathrm{~m}$ & $11379 \mathrm{~m}$ & $4.331 \mathrm{~m}$ & $6745 t$ \\
\hline Ocean Vulcan (满戴) & $\left(44 I^{\prime}\right.$ & $\left(416^{\prime}-0^{\prime \prime}\right)$ & $\left(56-10 \frac{3}{4} "\right)$ & $\left(37-4^{\prime}\right)$ & $8458 \mathrm{~m}$ & $13790 t$ \\
\hline
\end{tabular}

供された。な犒本船の実験結果の詳細は広渡氏の論文 ${ }^{(20)}$ に発表されている。s.s. Ocean Vulcan は Johnson ${ }^{(2)}$ によつてその実眏結果が発表されている全溶接の遮浪甲板型貨物船であつて，ここで解析を行なつたのはその一 連の実験の中の Series 7 (軽荷状態) 拈よび Series 11 (満載状態)についてである。

\section{$\S 10$. 山春丸の解析（軽荷状態）}

§4（2）の方法によつて求めた有効断面慣性モ ーメントの分布形状 $i \xi$ を Fig. 9 に示す。図中 実線で示したものは船楼の有効性を考虑に入れて 求めたもので, 点線は船楼が全長にわたつて有効 に㗢くとして普通の方法で求めたものを示す。本 船は長船橋楼を有するので, 船楼が完全に有効に 働く部分の長さはかなり大となる。すなわち(32) により $u=6.813$ となり, Fig. 3 より $2 \bar{z} / l=$ 0.654 を得, 船橋楼は中央部の $65.4 \%$ の範囲で 完全に有効に働く。な挆船体中央断面に括ける有 効慣性モーメント $I_{0}$ および剪断に対する有効断 面積 $A_{0}$ はそれぞれ

$$
I_{0}=39.4164 \mathrm{~m}^{4}, A_{0}=0.391 \mathrm{~m}^{2}
$$

となる。次に付加水質量を含めた船体重量の分布 形状 $q \xi$ は 4(1)の方法に従つて Fig. 10 に示 すごとくになる。契水 $d$, 排水量 $\Delta$ 执よび 2 次 元運動として求めた付加水質量 $\Delta^{\prime}$ はそれぞれ次 のごとくである。

$$
d=3.57 \mathrm{~m}, \Delta=5804 \mathrm{t}, \Delta^{\prime}=13637 \mathrm{t}
$$

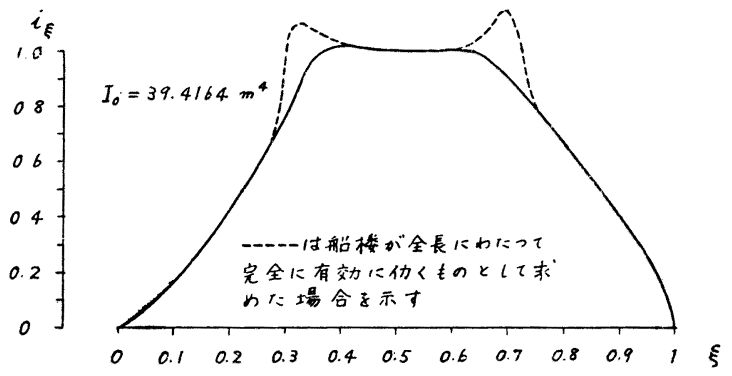

Fig. 9 山春丸の断面有效慣性亡ーメントの 分布形状 $i_{\xi}$

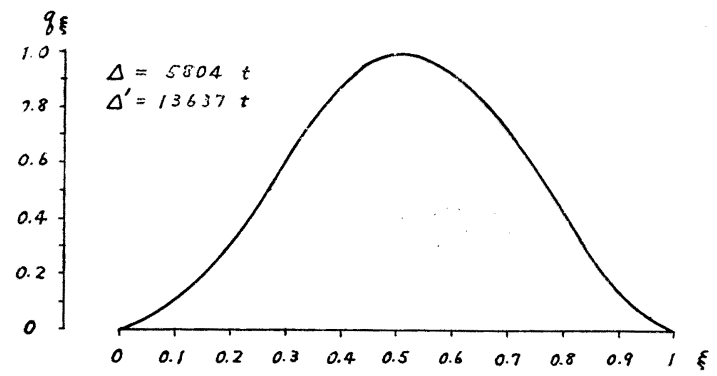

Fig. 10 山春丸の付加水質量を含め心船体重 量分布形状 $q \xi$ の影響を示す $(r / L)^{2}$ は (33)により，相当剪断係 数 $\beta_{1}$ は(31)によりそれぞれ

$$
\beta=0.0128, \quad(r / L)^{2}=0.00114, \quad \beta_{1}=0.0139
$$

となる。Fig. 9 㧊よび Fig. 10 の $i_{\xi}$ および $q \xi$ を船体中央に関し 対称分布となるよ

Table $5 \quad \alpha_{i m}(i, m=2,3,4,5,6)$

\begin{tabular}{|c|c|c|c|c|c|c|}
\hline$i_{1}^{m}$ & 2 & 4 & 6 & $i m$ & 3 & 5 \\
\hline 2 & 0932616 & -0138425 & -0030012 & 3 & 0773850 & -0200755 \\
4 & -0138425 & 0688304 & -0197400 & 5 & -0.200755 & 0684481 \\
6 & -0.030012 & -0.197400 & 0667874 & & &
\end{tabular}

Table $6 \quad R_{i m}(i=0,1,2,3,4,5,6 ; m=2,3,4,5,6)$

\begin{tabular}{|c|c|c|c|c|c|c|}
\hline$i m^{m}$ & 2 & 4 & 6 & $2 m$ & 3 & 5 \\
\hline 0 & -0.338180 & 0.060597 & 0.013164 & 1 & 0.064356 & -0.006469 \\
2 & 0418412 & -0.254115 & 0.002841 & 3 & 0.458026 & -0.255437 \\
4 & -0.254115 & 0.489350 & -0252277 & 5 & -0255437 & 0.499617 \\
\hline 6 & 0.002841 & -0.252277 & 0.505734 & & &
\end{tabular}

Table 7

$S_{i}$ および $T_{\text {i }}$

$(t=0,1,2,3,4,5,6)$

\begin{tabular}{|c|c|}
\hline$i$ & $S_{i}$ \\
\hline 0 & 0.512250 \\
2 & -0.338180 \\
4 & 0060597 \\
6 & 0013164 \\
\hline$i$ & $T_{i}$ \\
\hline 1 & 0017950 \\
3 & 0.064356 \\
5 & -0.006469 \\
\hline
\end{tabular}


Table 2 を用いて(23) により $\alpha_{i m}, R_{i m}, S_{i}, T_{i}$ を求めると Table $5,6,7$ に示す值が得られる。Table 5 , 6，7 および Table 1 を用い(24)によつて振動数方程式を作ると次のごとくになる。

$$
\left.\begin{array}{rl}
i=2: & C_{2}\left(466.834-0.195151 \Omega^{2}\right)+C_{4}\left(-374.440+0.214110 \Omega^{2}\right) \\
& +C_{6}\left(-200.470-0.011532 \Omega^{2}\right)=0 \\
i=4: & C_{2}\left(-374.440+0.214110 \Omega^{2}\right)+C_{4}\left(10061.4-0.482182 \Omega^{2}\right) \\
& +C_{6}\left(-7125.43+0.253834 \Omega^{2}\right)=0 \\
i=6: & C_{2}\left(-200.470-0.011532 \Omega^{2}\right)+C_{4}\left(-7125.43+0.253834 \Omega^{2}\right) \\
& +C_{6}\left(59531.2-0.505396 \Omega^{2}\right)=0
\end{array}\right\}
$$

\begin{tabular}{|c|c|c|c|}
\hline 次数 $i$ & $\Omega$ : & $c_{i}$ & 固有值 $c_{i} \Omega_{3}$ \\
\hline 2 萨振動 & 48.74 & 0.924 & 45.08 \\
\hline 了部振锄 & 173.6 & 0.779 & 88.49 \\
\hline 4 范搌烰力 & 198.2 & 2.649 & 128.6 \\
\hline
\end{tabular}

(53) および (54) につき係数行列式を 0 とおいた式を作ると

$$
\left.\begin{array}{l}
\text { 偶数節 : } \Omega^{6}-244414.4 \Omega^{4}+85276661 \times 10^{2} \Omega^{2}-18925409 \times 10^{6}=0 \\
\text { 奇数節 : } 0.05909135 \Omega^{4}-6528.6436 \Omega^{2}+74350989=0
\end{array}\right\}
$$

これを解いて $\Omega^{2}$ を求め，2６節振動に対する $\Omega$ が次のごとく得られる。(Fig. 1 参照)

$\Omega_{2}=48.786, \Omega_{3}=113.55, \Omega_{4}=198.21, \Omega_{5}=312.40, \Omega_{6}=450.37$

Table 8 山春丸の固有値（軽荷）
さきに求めた $\beta_{1}=0.0139$ に対して Fig. 2 により固有 值修正係数 $c_{i}$ を求めると Table 8 のごとくになり, 固有 値は $c \Omega$ として $2 \sim 4$ 節振動に対し Table 8 のごとくに なる (Fig. 15 参照)。

つぎに船底相当梁の $I_{e}$ 抢よび $m$ を求めるため, 船底を構 成する各部材の断面慣性モーメントを求めて $I_{\jmath}=0.00900$

$\mathrm{m}^{4}, I_{c}=0.04529 \mathrm{~m}^{4}, I_{s}=0.04376 \mathrm{~m}^{4}$ を得，付録 3 の方法により

$$
y_{c \max }=0.35992 \eta^{(c)}, \bar{y}_{c}=0.23171 \eta^{(c)}
$$

が得られる。従つて船底相当梁の $I_{e}$ は (51) により $e=0.72 \mathrm{~m}$ として

$$
I_{e}=0.04434 \mathrm{~m}^{4} / \mathrm{m}
$$

となる。船底相当梁の付加水質量 $M_{1}^{\prime}$ は (52) により $M_{1}{ }^{\prime}=100.88 \mathrm{t} / \mathrm{m}$, 相当梁の自重は $W_{1}$ $=5.53 \mathrm{t} / \mathrm{m}$ となり, 本船は載貨，バラスト共に 無く, 従つて船底相当梁の単位長さ当りの見掛 けの重量 $m$ は次のごとくになる。

$$
m=5.912 \mathrm{t} / \mathrm{m}^{2}
$$

さて(43)式中の $\beta l$ は(36)により

$$
\beta l=l \sqrt[4]{-E \omega^{2}}
$$

であるから，上に得られた数値を用い

$$
\beta l=0.5107 \sqrt{\omega}
$$

となり，（a）と Fig. 5 により船底相当梁の $K^{2}-\omega$ 曲線が Fig. 11 のごとくになる。次に 船体振動の $K^{2}-\omega$ 曲線を求めるため, 先ず Fig. 6 により $L_{B P} / B=7.44$ として $J_{2}=0.746$, $J_{3}=0.664$ を得るから既に得た值を用いて(47) により

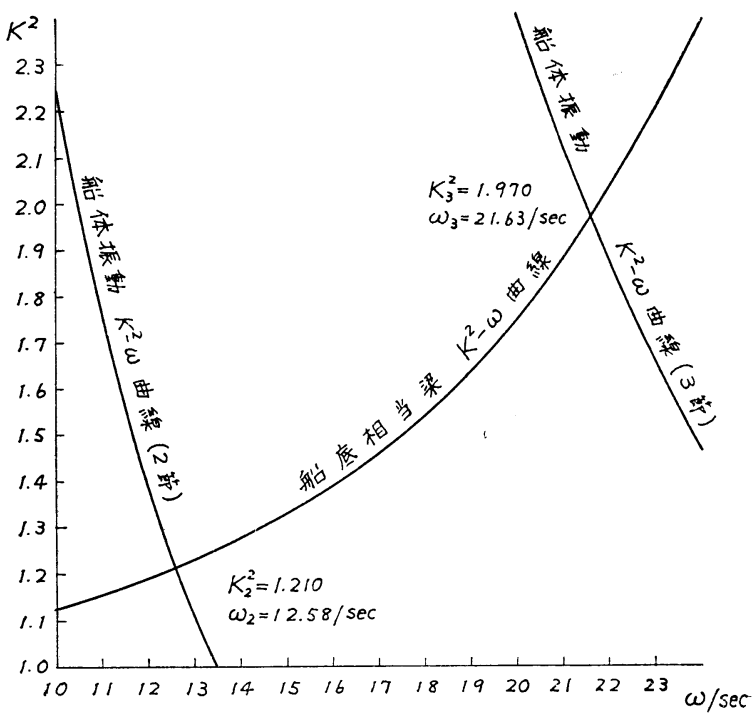

Fig. 11 山春丸 $K^{2}-\omega$ 曲線（軽荷状態）

$$
2 \text { 節 : } K_{2}{ }^{2}=\frac{1}{10173}\left(\frac{2870870}{\omega^{2}}-5804\right), \quad 3 \text { 節 }: K_{3}{ }^{2}=\frac{1}{9055}\left(\frac{11061900}{\omega^{2}}-5804\right)
$$

が得られる。これより $K^{2}-\omega$ 曲線を作ると Fig. 11 のごとくになる。

Fig. 11 に特ける各 $K^{2}-\omega$ 曲線の交点の座標として 
2 節 : $K_{2}^{2}=1.210, \omega_{2}=12.58 / \mathrm{sec}$

3 節 : $K_{3}^{2}=1.970, \omega_{3}=21.63 / \mathrm{sec}$

が得られ，これより付加水質量は $K^{2} J \Delta^{\prime}$ として

$$
2 \text { 節 : } K_{2}{ }^{2} J_{2} \Delta^{\prime}=12310 \mathrm{t} \quad 3 \text { 節 : } K_{3}{ }^{2} J_{3} \Delta^{\prime}=17840 \mathrm{t}
$$

となる。付加水質量を含めた船体重量 $\Delta_{1}$ は 2 節 : $\Delta_{1}=18110 \mathrm{t}, 3$ 節 : $\Delta_{1}=23640 \mathrm{t}$ となり, $\Delta_{1} / \Delta$ の比は 2 節 および 3 節に対しそれぞれ 3.12 および 4.07 となる。

船体固有振動数は $N=60 \omega / 2 \pi(\mathrm{c} / \mathrm{min})$ として

2 節 : $N_{2}=120.1 \mathrm{c} / \mathrm{min} \quad 3$ 節 : $N_{3}=206.5 \mathrm{c} / \mathrm{min}$

となり，これに対し实测值は $N_{2}=120 \mathrm{c} / \mathrm{min}, N_{3}=205 \mathrm{c} / \mathrm{min}$ であつて計算值と笑测值はよく一致する。

\section{$\S 11$. Ocean Vulcan の解析（軽荷および満載状態）}

Johonson ${ }^{(2)}$ によつて発表された資料にもとづき Ocean Vulcan の軽荷および満載状態について山春丸と同様

にして解析を行なつた結果を示すと次のごとくにな

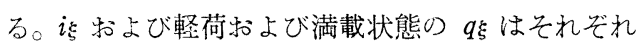
Fig. 12，13，14 に示すごとくになり，船体中央断 面における有效慣性モーメント $I_{0}$ および剪断に対 する有効断面積 $A_{0}$ は年れぞれ

$$
I_{0}=25.1342 \mathrm{~m}^{4}, A_{0}=0.3794 \mathrm{~m}^{2}
$$

2 次元運動として求めた付加水質量 $\Delta^{\prime}$ は

軽荷: $\Delta^{\prime}=12726 \mathrm{t}$, 満載: $15452 \mathrm{t}$

となる。剪断の影響を示す $\beta$ は $\beta=0.00951$ とな り，回転慣性については本船は軽荷状態では 2 重底 内に六ストを有するが艙内貨物はなく，満載状態 では艙内貨物を有するが 2 重底内にはバラストがな く，艙内貨物の種類，載貨状態拉よび正確な重量が 不明であつたので， $(\boldsymbol{r} / L)^{2}$ の值としては軽荷状態 のものを共通に用い $(r / L)^{2}=0.00097$ とした。従 つて相当剪断係数 $\beta_{1}$ は軽荷ふよび満載状態に対し

$$
\beta_{1}=0.0105
$$

そ用いた。以上の資料より前と同様にして振動数方 程式を作り，これを解いて $2 \sim 6$ 節振動に対する $\Omega$ が次のごとくになる (Fig. 1 参照)。

軽荷 : $\Omega_{2}=43.900, \Omega_{3}=109.68, \Omega_{4}=201.75$,

$$
\Omega_{5}=332.33, \Omega_{6}=486.14
$$

満載 : $\Omega_{2}=32.786, \Omega_{3}=82.814, \Omega_{4}=156.11$, $\Omega_{5}=253.96, \Omega_{6}=369.46$

$\beta_{1}=0.0105$ に対し Fig. 2 により固有值修正係数 $c_{i}$ を求め, 本船の $2 \sim 4$ 節振動に対する固有值 $c \Omega$ は Table 9 に示すごとくになる。以上の結果を山春 丸のものと共に Fig. 15 に示す。

つぎに船底相当梁の $I_{e}$ 牰よび $m$ を前と同様に

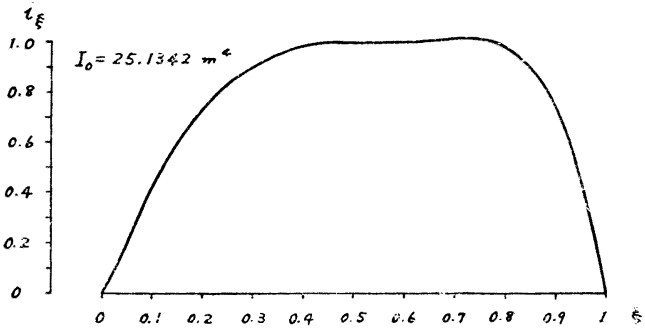

Fig. 12 Ocean Vulcan の断面有効慣性 モーメントの分布形状 $i_{\xi}$

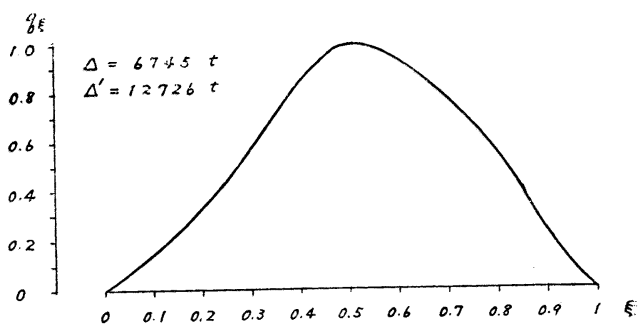

Fig. 13 Ocean Vulcan 9 付加水質量を 含めた船体重量分布形状 $q_{\xi}$ （軽荷状態）

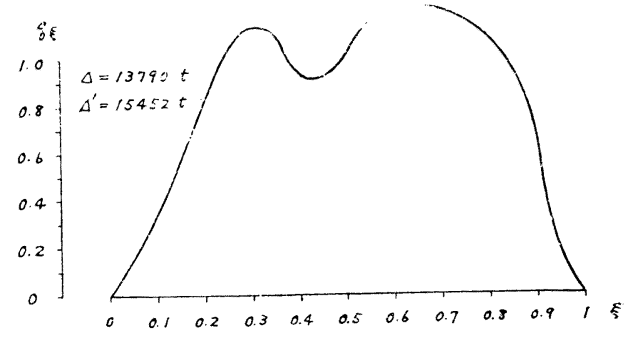

Fig. 14 Ocean Vulcan の付加水質量 含めた船体重量分布形状 $q_{\xi}$ (满載状態)

Table 9 s.s. Ocean Vulcan の固有值（軽荷および满載）

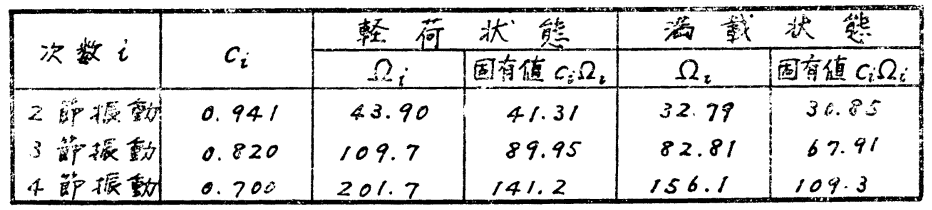




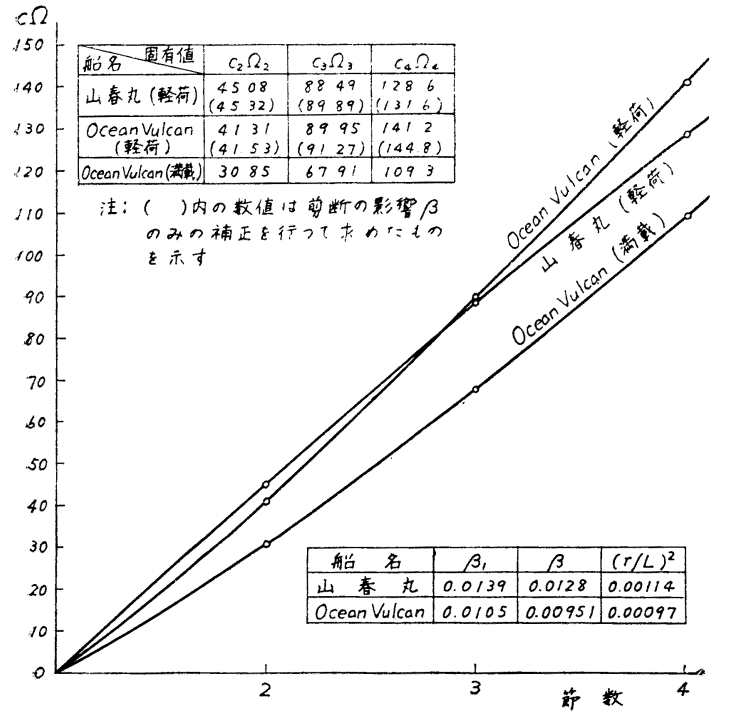

Fig.15 山春丸拉よび Ocean Vulcan の固有值
して求めると

$$
I_{e}=0.03099 \mathrm{~m}^{4} / \mathrm{m}, \quad m=7.389 \mathrm{t} / \mathrm{m}^{2}
$$

となるが，mは先に述べたように満載状態での載 貨の詳細が不明であつたので，軽荷状態での值を 共通に用いた。このようにしても $m$ の值を決定 する支配的なるのは船底相当梁汇対する付加水質 量 $M_{1}{ }^{\prime}$ であるので結果には汪とんど影響はない。

以上の值怙よび Fig. 5 によつて軽荷拉よび满 載状態に対し共通淿船底相当梁の $K^{2}-\omega$ 曲線が得 られ Fig. 16 のごとくになる。つぎに船体振動 の $K^{2}-\omega$ 曲線も前と同様にして Fig. 16 亿示す ごとくになる。な打本船の付加水質量に対する 3 次元運動修正係数 $J$ は $L_{B P} / B=7.31$ として, Fig. 6 より $J_{2}=0.739, J_{3}=0.659$ となる。

Fig. 16 に抹ける各 $K^{2}-\omega$ 曲線の交点の座標と して

軽荷 2 節 : $K_{2}{ }^{2}=1.220, \omega_{2}=10.34 / \mathrm{sec}$ 3 節 : $K_{3}{ }^{2}=2.280, \omega_{3}=18.88 / \mathrm{sec}$ 满載 2 節: $K_{2}^{2}=1.120$,

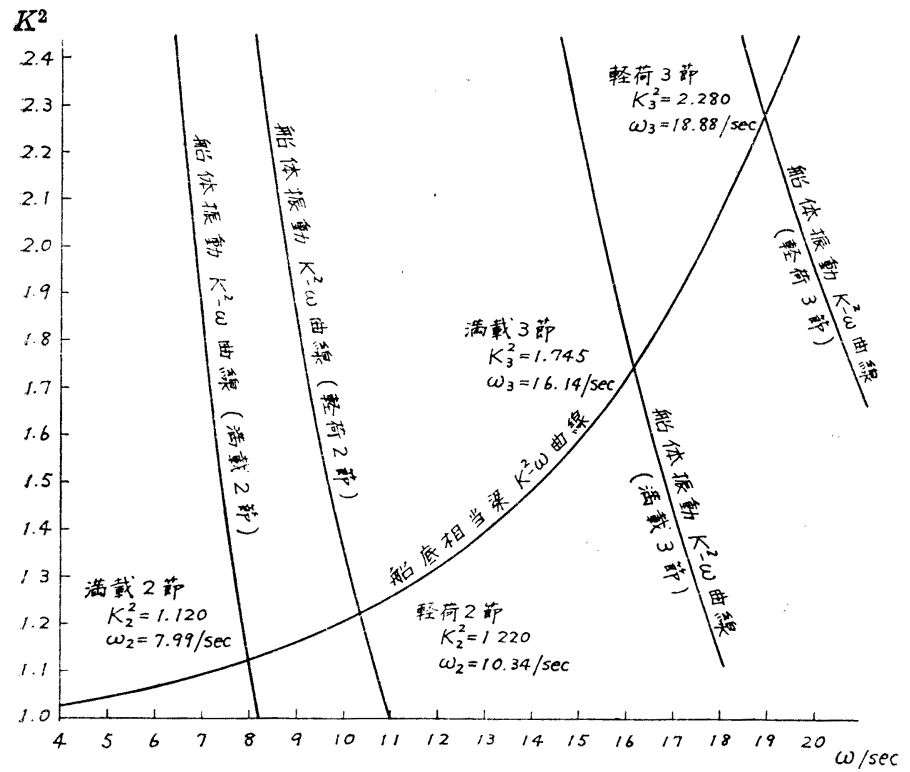

Fig. 16 Ocean Vulcan $K^{2}-\omega$ 曲線（軽荷抢よび満載状態）

$$
\omega_{2}=7.99 / \mathrm{sec}
$$

3 節: $K_{3}^{2}=1.745$,

が得られ，これより付加水質量は $K^{2} J \Delta^{\prime}$ として

軽荷 2 節 : $K_{2}^{2} J_{2} \Delta^{\prime}=11470 \mathrm{t}$ 3 節 : $K_{3}^{2} J_{3} \Delta^{\prime}=19120 \mathrm{t}$

満載 2 節 : $K_{2}^{2} J_{2} \Delta^{\prime}=12790 \mathrm{t}$ 3 節 : $K_{3}^{2} J_{3} \Delta^{\prime}=17770 \mathrm{t}$ となる。付加水質量を含めた船体重 量 $\Delta_{1}$ は軽荷状態のとき, 2 節： $18220 \mathrm{t}, 3$ 節 : $25870 \mathrm{t}$, 満載状態の とき, 2 節 : $26580 \mathrm{t}, 3$ 節 $: 31560 \mathrm{t}$ となり, $\Delta_{1} / \Delta$ の比は 2 節および 3 節に対し，軽荷状態では 2.70 少上 び 3.84 ，満載状態では 1.93 特よび 2.29 となる。

船体固有振動数 $N=60 \omega / 2 \pi(\mathrm{c} /$ $\omega_{3}=16.14 / \mathrm{sec}$ $\min )$ とて

$$
\begin{array}{lll}
\text { 軽荷 } 2 \text { 節 : } N_{2}=98.7 \mathrm{c} / \mathrm{min} & 3 \text { 節 : } N_{3}=180.3 \mathrm{c} / \mathrm{min} \\
\text { 満載 } 2 \text { 節 }: N_{2}=76.3 \mathrm{c} / \mathrm{min} & 3 \text { 節 }: N_{3}=154.1 \mathrm{c} / \mathrm{min}
\end{array}
$$

となり，これに対し実測值は軽荷： $N_{2}=100 \mathrm{c} / \mathrm{min}, N_{3}=185 \mathrm{c} / \mathrm{min}$ ，満載： $N_{2}=77 \mathrm{c} / \mathrm{min}, N_{3}=156 \mathrm{c} / \mathrm{min}$ であ る。山春丸拈よび Ocean Vulcan の結果をまとめて Fig. 17 亿示す。

\section{結言}

以上貨物船垂直撓み振動の解析について述べたが，実船の解析結果よりつぎの結論が得られる。

（1）船体有効曲げ剛性の算定に当つては普通の貨物船では甲板室を無視して差し支觉なく，三島型貨物船の 
場合は船橋楼の有効度を §4（2）の方法によつて算定すれば 上い。

（2）付加水質量汶対する 3 次元運動修正係数 $J$ の値は $L / B=7 \sim 8$ の普通の船体では曲将飞よる船体横断面の回転 の影響仗より Lewis の値より幾分小さくなる。

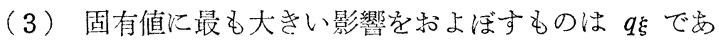
る。(Ocean Vulcan の軽荷お上び満載状態の固有值参照)

（4）固有值に招よぼすi乡の影響はそれ程大きくない。 （軽荷状態に拈ける山春丸と Ocean Vulcan の固有值参照）

（5）船体垂直撓又振動の付加水質量は従来水面下の船体 の形状，寸法拉よび振動の次数によつて定まると考兄られて

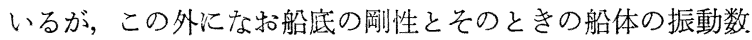
との相互影響沈って定まるべき修正係数 $K^{2}$ を必要とす る。

最後に本研究を行ならに当り御指導を睗わつた大阪大学寺 沢一雄教授並びに実船の解析に際し山春丸に関する詳細な資 料を提供された日立造船技術研究所広渡智雪氏に対し厚く御

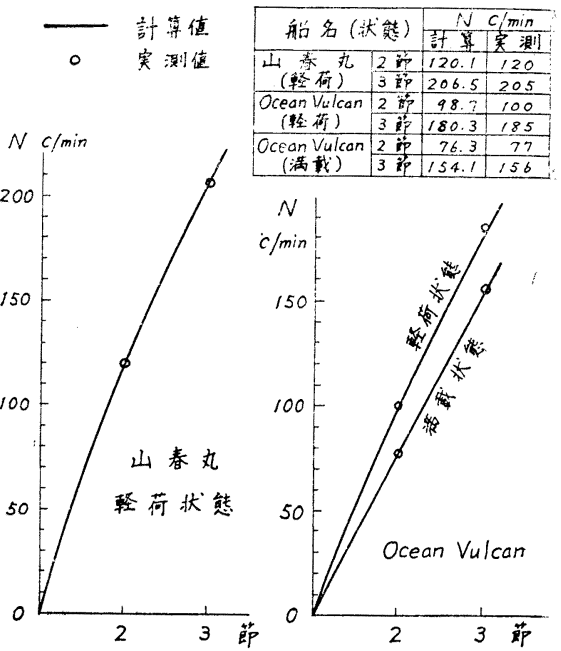

Fig. 17 山春丸および Ocean Vulcan の固有振動数

礼申上げます。また各種の数值計算および実船の解析に対して協力された当時の大阪大学工学部大学院学生近藤 淳氏*沉対して感謝の意を表する次第である。

\section{参 考 文 献}

（1）熊井豊二：剪断振動としての船体高次振動について，造船協会論文集，第 99 号

(2) A. J. Johnson: Vibration Tests of All-Welded and All-Riveted 10,000 ton Dry Cargo Ship, N. E. C. I., Vol. 67, 1950-51

(3) J.E. Richards : An Analysis of Ship Vibration Using Basic Functions, N.E.C.I., Vol. 68, 1951-52

（4）広渡智雪：船体固有振動数の研究（第 4 報），造船協会論文集，第 102 号

（5）著者：剪断の影響を考虑した両端自由梁の屈曲振動（一㥞断面梁の場合），関西造船協会誌，第 94 号

（6）寺呮一雄, 著者：Transverse Vibration of Higher Frequencies of Beams of Uniform Cross Section Taking into Account the Effect of Shear, 大阪大学工学報告, 第 8 卷, Oct., 1958

（7）柴垣和三堆：数値積分法（応用数学第 9 巻, 河出）及び倉西正嗣：弾性学

(8) C.E. Inglis : The Determination of Critical Speeds, Natural Frequencies and Modes of Vibration By Means of Basic Function, N.E.C.I., Vol. 61, 1944-45

(9) C.W. Prohaska: The Vertical Vibration of Ships, The Shipbuilder \& Marine Eng.-builder, Oct.-Nov., 1947

(10) F.M. Lewis: The Inertia of the Water Surrounding a Vibrating Ship, S. N. A. M. E., Vol. 37, 1929

(11) J.L. Taylor : Some Hydrodynamical Inertia Coefficients, Phil. Mag., Vol. 9, 1930

(12) J. L. Taylor: Vibration of Ships, T. I. N. A., Vol. 72, 1930

(13) H. H. Bleich : Nonlinear Distribution of Bending Stress Due to Distortion of the Cross Section,

J. App. Mech., 1953

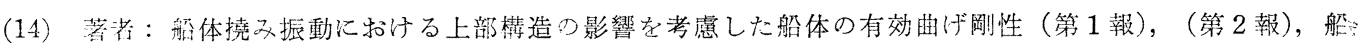
体棈造委員会関西地区部会資料，関西 59-10-29 抢よび関西 59-12-43

（15）著者：船体横断面の剪断剛性，船体構造委員会関西地区部会資料，関西 59-4-13

* 日立造船技術研究所 
(16) W. Hovgaard : Structural Design of Warships.

(17) W. Schilling : Statik der Bodenkonstruktion der Schiffe, 1925

（18）奥田克已，有馬 孝：縦横に防撓材を有する矩形薄板の強さ及び固有振動数，造船協会会報，第 58 号, 昭和 11 年

（19）鬼頭史城：水中に於て振動する平面板の附加質量について, 造船協会雑篹, 第 266 号, 昭和 19 年

(20) 広渡智雪: 船体固有振動数の研究（第 3 報）, 造船協会論文集, 第 97 号

(21) Timoshenko and Goodier : Theory of Elasticity, 1951 年版, p. 40

（22）寺沢一雄，八木順吉：上部構造の効きに関する研究 (第 3 報), 造船協会論文集, 第 102 号

(23) H. Lamb: Hydrodynamics, 4 th edition.

付録 1. 船楼の影響を考慮した船体有効断面慣性モーメント

船体を主構造扣よび船楼共に一様断面, 且つ前後対称と考兄, 主構造と船楼の間のバネ定数を $K$, 船楼揖よ び主構造の撓みをそれぞれ $y_{1}$ および $y_{2}$ とすれば，Bleich(13) により曲げに対する基礎方程式は次式によつて 与えられる。

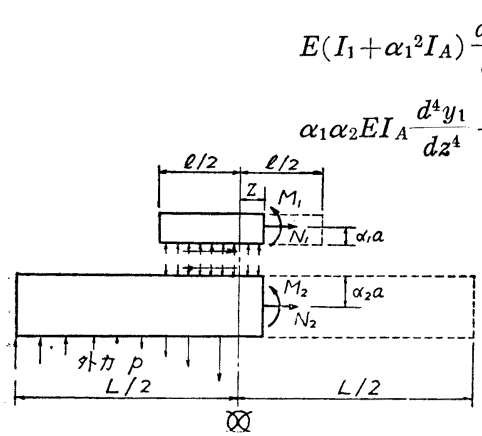

Fig. 18

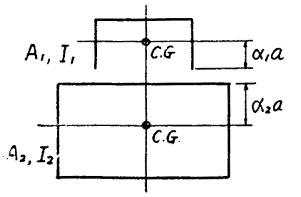

Fig. 19

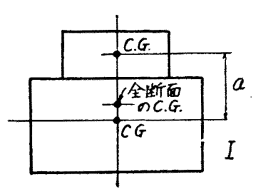

与えられた荷重に対して（57）の解が得られると，船体の有効断面慣性モーメントは次のごとく考觉て求めら れる。船体の撓みは主構造の撓み $y_{2}$ によつて表わされるものと考文, 主構造の曲率 $d^{2} y_{2} / d z^{2}$ に等しい曲率をも つような可変断面梁の断面慣性モーメント $I_{e}$ を以て有効慣性モーメントとする。従つて主構造および船体全断 面に㗢く曲げモーメントをそれぞれ $M_{2}$ および $M$ とすれば

$$
\frac{d^{2} y_{2}}{d z^{2}}=-\frac{M_{2}}{E I_{2}}=-\frac{M}{E I_{e}} \quad \therefore \quad I_{e}=I_{2} \frac{M}{M_{2}}=-\frac{1}{E} \frac{M}{\frac{d^{2} y_{2}}{d z^{2}}}
$$

によつて $I_{e}$ が求められる。

種々の荷重状態につき（57）の解を求め (60) によつて $I_{e}$ を求めた結果， $I_{e}$ は荷重状態によつてほとんど影 響されず，船体の構造，寸法のみによつて定まると考えてもよいことが判つたので(14)，ここでは一梾曲げの場 合の解を用いて $I_{e}$ を求め次の結果を得る。

$$
I=\frac{1}{1+\frac{\mu}{1-v(1+\mu)}\left(\Phi_{1} \cos \gamma z \cosh \gamma z-\Psi_{1} \sin \gamma z \sinh \gamma z\right)}
$$




$$
\left.\begin{array}{c}
\Phi_{1}=\frac{\cos u \sinh u+\sin u \cosh u}{\sin u \cos u+\sinh u \cosh u}, \quad \Psi_{1}=\frac{\cos u \sinh u-\sin u \cosh u}{\sin u \cos u+\sinh u \cosh u} \\
v=\begin{array}{c}
\alpha_{1} \alpha_{2} I_{A} \\
I_{1}+\alpha_{1} I_{A}
\end{array}, \quad u=\frac{l}{2} \sqrt[4]{\frac{K}{4 E}} \\
\alpha_{2} I_{1}+\mu \alpha_{1} I_{2}
\end{array}\right)
$$

船体中央に拈ける $I_{e}$ を $I_{e 0}$ とすれば（61）より $z=0$ と拉いて

$$
I_{e 0}=\frac{1}{1+\frac{\mu \Phi_{1}}{1-v(1+\mu)}}
$$

となる。今 1 例としてある実船についての $\mu, v$ の值を用い $u=1,2,3,4,5$ のとき の $I_{e} / I$ を(61) によつて求めると Fig. 20 の 如くになり，uの值が約 2.4 以上になると船 体中央部のある範囲内では $I_{e} / I \geqq 1$ となり 全断面が完全に有効に働くことが判る。そこ で近似法として全断面が有効に働く部分では $I_{e} / I=1$ とし, 船楼端における值を $I_{2} / I$ とし て両者の間を直線で結べば Fig. 20 は Fig. 21 のごとくになり実用上十分な近似值が得 られる。Fig. 21 の作図法に沶いて $I_{e} / I=1$

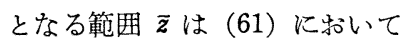

\section{$\Phi_{1} \cos \gamma z \cosh \gamma z$}

$$
-\Psi_{1} \sin \gamma z \sinh \gamma z=0
$$

を満足する $\gamma \boldsymbol{z}$ の值を $(\gamma z)_{0}$ とすれば $\bar{z}= \pm$ $(\gamma z)_{0} / r= \pm(r z)_{0} l / 2 u$ となり, 船楼が完全に 有効に動く長さ $2 \bar{z}$ は

$$
\frac{2 \bar{z}}{l}=\frac{(\gamma z)_{0}}{u}
$$

によつて与えられる。(65) の右辺は $u$ のみ の函数として求まり， $2 \bar{z} / l$ は本文 Fig. 3 に 示したごとくuの值によつて直ちに求めら

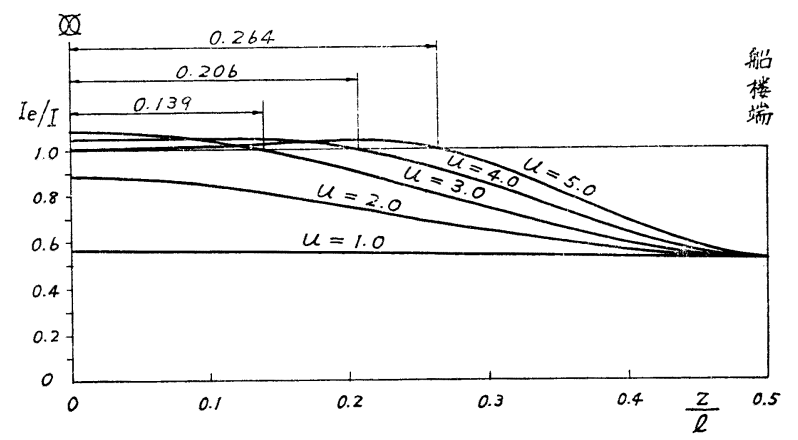

Fig. 20 船楼の長さに沿 $5 I_{e} / I$ の分布

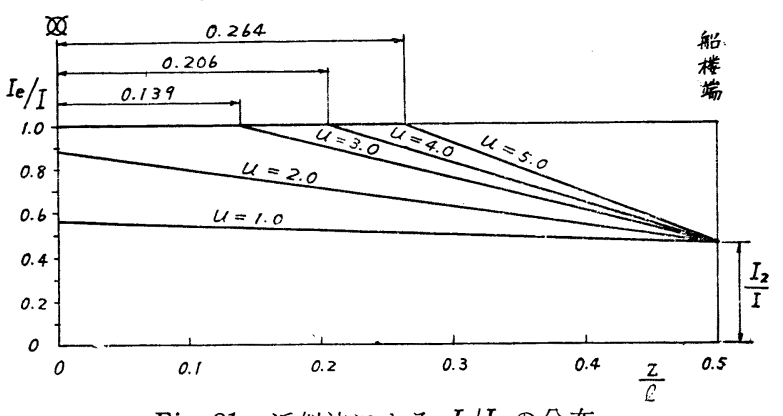

Fig. 21 近似法による $I_{e} / I$ の分布
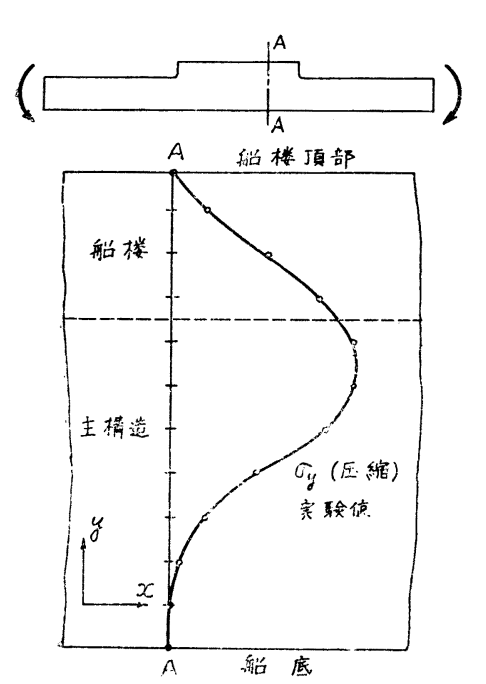

Fig. 22

れる。ただし $u<2.37$ の場合は（63）による。

つぎに船楼と主構造の間のバネ定数 $K$ の算定は, 両者の間の力の伝 達が船側外板を通じて行われると考えて次のようにした。Fig. 22 は著 者が以前に行なつた光弾性実験の結果の 1 例であつて， $\sigma_{y}$ の分布は主 構造および船楼の各々につき Fig. 23 のごとく両端支持等分布荷重の 矩形断面梁の $\sigma_{y}$ の分布形状 ${ }^{(21)}$

$$
\sigma_{y}=-\frac{3 q}{4 c^{3}}\left(\frac{1}{3} y^{3}-c^{2} y+\frac{2}{3} c^{3}\right)
$$

によく似ている。従つて船楼扣よび主構造船側外板の肋骨断面積を含め た相当板厚をそれぞれ $t_{1}$ 特よび $t_{2}$, 深さをそれぞれ $D_{1}$ および $D$, 両 者の拉よぼし合う圧力を単位長さ当り $q_{0}$ とし，船楼に対しては(66)に

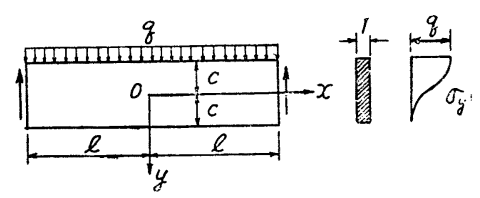

Fig. 23 
沶いて $c=D_{1} / 2, q=q_{0} / t_{1}$, 主構造に対しては $c=D / 2, q=q_{0} / t_{2}$ として各々の歪 $\varepsilon_{y 1}, \varepsilon_{y 2}$ を求めると, 両者の中 性軸間の距離変化 $\Delta a$ は

$$
\Delta a=\int_{-\frac{D_{1}}{2}}^{\alpha_{1} a-\frac{D_{1}}{2}} \varepsilon_{y_{1}} d y+\int_{-\frac{D}{2}}^{\alpha_{2} a-\frac{D}{2}} \varepsilon_{y 2} d y
$$

となり，バネ定数 $K$ は船側外板が左右両去にあることを考虑して $K=-2 q_{0} / \Delta a$ として次式のごとくになる。

$$
K=\frac{4 E}{a} /\left[\begin{array}{c}
\alpha_{1} \\
t_{1}
\end{array}\left\{2-2\left(\frac{\alpha_{1} a}{D_{1}}\right)^{2}+\left(\frac{\alpha_{1} a}{D_{1}}\right)^{3}\right\}+\frac{\alpha_{2}}{t_{2}}\left\{2-2\left(\frac{\alpha_{2} a}{D}\right)^{2}+\left(\frac{\alpha_{2} a}{D}\right)^{3}\right\}\right]
$$

な怙上記の $K$ の值は $\sigma_{y}$ の分布をさらに簡単な形に仮定して求められた寺沢教授括よび八木助教授(22)の方法 による值と添とんど差異はない。

付録 2. 付加水質量の 3 次元運動修正係数 $\boldsymbol{J}$

重直撓㕛振動における付加水質量の 3 次元運動修正係数 $J$ を回転楕円体の場合について，曲げに上る梁断面 の回転の影響を考虑に入れた境界条件の下で求めた。記号抢よび解法の主方針は Lewis ${ }^{(10)}$ と同様である。

棈円座標 $\zeta, \mu, \omega$ を用い回転棈円体の 周囲の水の持つ速度ポテンシヤルを $\phi$ とすれば $\nabla^{2} \phi=0$ の一般解は $\mathrm{Lamb}^{(23)}$ により

$$
\left.\phi=P_{n}^{s}(\mu) Q_{n}^{s}(\zeta) \begin{array}{c}
\cos \\
\sin
\end{array}\right\} s \omega \quad(s, n=1,2,3, \cdots \cdots)
$$

ここに $P_{n}^{s}(\mu), Q_{n}^{s}(\zeta)$ は夫々 Legendre の第 1 種拉よび第 2 種陪函数である。 2 節， 3 節および 4 節振動の場 合の $\phi$ を次の形扎く。

$$
\left.\begin{array}{l}
2 \text { 節 : } \phi=\left\{\beta_{1} P_{1}{ }^{1}(\mu) Q_{1}{ }^{1}(\zeta)+\beta_{3} P_{3}{ }^{1}(\mu) Q_{3}{ }^{1}(\zeta)\right\} \cos \omega \\
3 \text { 節 : } \phi=\left\{\beta_{2} P_{2}{ }^{1}(\mu) Q_{2}{ }^{1}(\zeta)+\beta_{4} P_{4}{ }^{1}(\mu) Q_{4}{ }^{1}(\zeta)\right\} \cos \omega \\
4 \text { 節 : } \phi=\left\{\gamma_{1} P_{1}{ }^{1}(\mu) Q_{1}{ }^{1}(\zeta)+\gamma_{3} P_{3}{ }^{1}(\mu) Q_{3}{ }^{1}(\zeta)+\gamma_{5} P_{5}{ }^{1}(\mu) Q_{5}{ }^{1}(\zeta)\right\} \cos \omega
\end{array}\right\}
$$

ここに $\beta_{1}, \beta_{2}, \beta_{3}, \beta_{4}, \gamma_{1}, \gamma_{3}, \gamma_{5}$ は任意定数で境界条件によつて定められる。これより流体の運動エネルギー $T$ は流体の密度を $\rho$ ，回転棈円体表面の面素を $d S$ として

$$
2 T=-\rho \int_{-1}^{1} \int_{0}^{2 \pi}\left(\phi \frac{\partial \phi}{\partial n}\right)_{\zeta=\zeta_{0}} d S, \quad d S=r d \omega d S \mu=k^{2}\left(\zeta_{0}^{2}-\mu^{2}\right)^{\frac{1}{2}}\left(\zeta_{0}^{2}-1\right)^{\frac{1}{2}} d \mu d \omega
$$

によつて求められる(10) $\left(\xi=\zeta_{0}\right.$ は回転棈円体表面, $n$ は法線方向を示す)

一方撓み曲線の形を仮定し，撓み振動速度 $v$ を

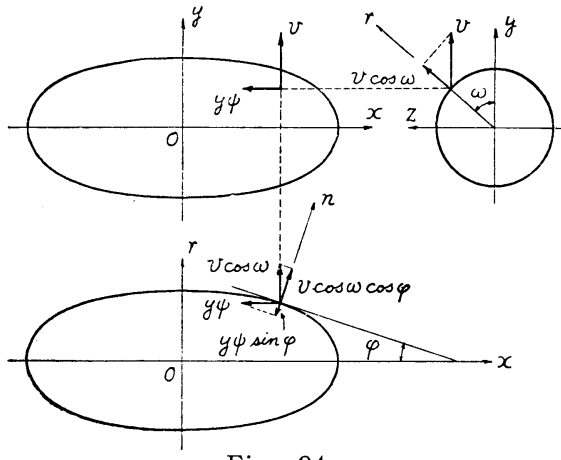

$\left.\begin{array}{l}2 \text { 節 : } v=\mu^{2}-a_{2}^{2}, 3 \text { 節 : } v=\mu\left(\mu^{2}-a_{3}{ }^{2}\right), \\ 4 \text { 節 }: v=\left(\mu^{2}-a_{4}{ }^{2}\right)\left(\mu^{2}-b_{4}{ }^{2}\right)\end{array}\right\}$

とおけば，断面の曲げによる回転角速度

2 節 : $\psi=\frac{2}{k \zeta_{0}} \mu, 3$ 節 $: \psi=\frac{1}{k \zeta_{0}}\left(3 \mu^{2}-a_{3}^{2}\right)$,

4 節 : $\psi=\frac{2}{k \zeta_{0}} \mu\left\{2 \mu^{2}-\left(a_{4}{ }^{2}+b_{4}^{2}\right)\right\}$

となる。ここに $a_{2}, a_{3}, a_{4}, b_{4}$ は撓み曲線の節点の位置を示す 定数でめる。これより回転楕円体表面の点の持つ法線方向の速 度 $v_{n}$ は Fig. 24 に示すごとく

$v_{n}=v \cos \omega \cos \varphi-y \psi \sin \varphi=\frac{\left(1-\mu^{2}\right)^{1 / 2}}{\left(\zeta_{0}^{2}-\mu^{2}\right)^{1 / 2}}\left\{v \zeta_{0}-\psi k \mu\left(\zeta_{0}^{2}-1\right)\right\} \cos \omega$

となり，境界条件は

$$
-\left(\frac{\partial \phi}{\partial n}\right)_{\zeta=\zeta_{0}}=v_{n}
$$

によつて与えられる。Lewis の解は境界条件に拉いて $\psi$ の項を無視して求められたものである。

境界条件 (75) 汇より任意定数 $\beta_{1}, \beta_{2}, \beta_{3}, \beta_{4}, \gamma_{1}, \gamma_{3}, \gamma_{5}$ が決定され, 運動エネルギー $T$ が求められる。 一方流体の運動を 2 次元と考えた場合の運動エネルギー $T^{\prime}$ を求めると，3次元運動修正係数 $J$ は $J=T / T^{\prime}$ と 
して与えられ，計算の結果次式のごとくになる。

$$
\begin{aligned}
& 2 \text { 節 : } J_{2}=\left[\frac{1}{25}\left(1+5 a_{2}{ }^{2}-\frac{2}{\zeta_{0}^{2}}\right)^{2} R_{1}+\frac{24}{525}\left(1-\frac{2}{\zeta_{0}^{2}}\right)^{2} R_{3}\right] /\left[\left(\frac{1}{5}-a_{2}{ }^{2}\right)^{2}+\frac{8}{175}\right]
\end{aligned}
$$

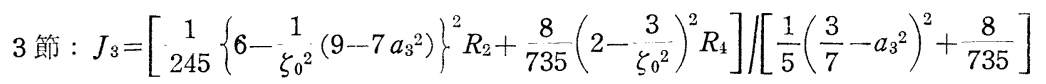

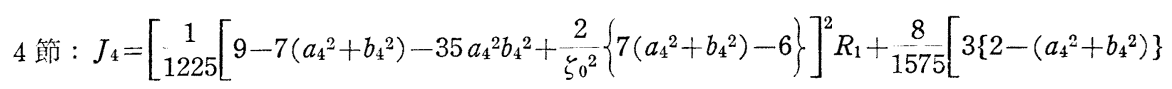

$$
\begin{aligned}
& \left.\left.+\frac{2}{\zeta_{0}^{2}}\left\{3\left(a_{4}{ }^{2}+b_{4}{ }^{2}\right)-4\right\}\right]^{2} R_{3}+\frac{64}{24225}\left(3-\frac{4}{\zeta_{0}^{2}}\right)^{2} R_{5}\right] /\left[a_{4}{ }^{4} b_{4}{ }^{4}+\frac{6}{35} a_{4}{ }^{2} b_{4}{ }^{2}\right. \\
& \left.-\frac{2}{5} a_{4}{ }^{2} b_{4}{ }^{2}\left(a_{4}{ }^{2}+b_{4}{ }^{2}\right)+\frac{3}{35}\left(a_{4}{ }^{2}+b_{4}{ }^{2}\right)^{2}-\frac{2}{21}\left(a_{4}{ }^{2}+b_{4}{ }^{2}\right)+\frac{1}{33}\right]
\end{aligned}
$$

ここに $R_{1}, R_{2}, R_{3}, R_{4}$ は Lewis ${ }^{(10)}$ によつて与兄られたものと同じであつて $R_{5}$ は次式のごときものである。

$$
R_{5}=-\frac{\frac{1}{2}\left(315 \zeta_{0}^{5}-210 \zeta_{0}^{3}+15 \zeta_{0}\right) \log \frac{\zeta_{0}+1}{\zeta_{0}-1}-\frac{315 \zeta_{0}^{6}-420 \zeta_{0}^{4}+113 \zeta_{0}^{2}}{\zeta_{0}^{2}-1}}{\frac{1}{2}\left(1575 \zeta_{0}{ }^{5}-1890 \zeta_{0}{ }^{3}+435 \zeta_{0}\right) \log \frac{\zeta_{0}+1}{\zeta_{0}-1}-\frac{1575 \zeta_{0}{ }^{6}-2940 \zeta_{0}{ }^{4}+1485 \zeta_{0}{ }^{2}-128}{\zeta_{0}-1}}
$$

節点の位置として 2 節抢よび 3 節に対しては Lewis ${ }^{(10)}$ と同様に， $a_{2}=1 / \sqrt{5}=0.447, a_{3}=\sqrt{3 / 7}=0.65$ とし， 4 節に対しては

$$
a_{4}=\sqrt{(7-\sqrt{28}) / 21}=0.29, \quad b_{4}=\sqrt{(7+\sqrt{28}) / 21}=0.77
$$

とすれば実船の計測結果にかなり近いるのとなり，(76) は次式の如くになる。

$$
\left.\begin{array}{l}
2 \text { 節 : } J_{2}=\frac{7}{2}\left(1-\frac{1}{\zeta_{0}^{2}}\right)^{2} R_{1}+\left(1-\frac{2}{\zeta_{0}^{2}}\right)^{2} R_{3} \\
3 \text { 節 : } J_{3}=\frac{27}{2}\left(1-\frac{1}{\zeta_{0}^{2}}\right)^{2} R_{2}+\left(2-\frac{3}{\zeta_{0}^{2}}\right)^{2} R_{4} \\
4 \text { 節 : } J_{4}=\frac{1}{5}\left(1-\frac{1}{\zeta_{0}^{2}}\right)^{2}\left(11 R_{1}+154 R_{3}\right)+\left(3-\frac{4}{\zeta_{0}^{2}}\right)^{2} R_{5}
\end{array}\right\}
$$

$L / B=5 \sim 12$ の範囲について (78) によつて求めた $J$ の值は本文 Fig. 6 のごとくになる。

付録 3. 2 重底の曲げ岡性

船の幅を $l$, 横隔壁間の距離を $l_{1}$ とすれば 2 重底は本文 Fig. 8 亿示すごとく船側で単純支持, 隔壁で固定 の平面格子構造と考兄られる。 2 重底に働く単位面積当り $q$ の垂直等分布荷重を先ず横部材に分配し, 鎚部材 はこれらを弾性的に支持するものと考兄ると, Schilling(17) の考兄方を適用して centre girder 扣よび side girder の撓みを $y_{c}$ 抢よび $y_{s}$ として次の基礎方程式が得られる。

$$
\begin{aligned}
& \frac{\lambda}{\rho_{c}} \frac{d^{4} y_{c}}{d z^{4}}+\frac{2 \mu}{\rho_{s}} \frac{d^{4} y_{s}}{d z^{4}}+y_{c}=\eta^{(c)} \\
& \frac{\mu}{\rho_{c}} \frac{d^{4} y_{c}}{d z^{4}}+\frac{v}{\rho_{s}} \frac{d^{4} y_{s}}{d z^{4}}+y_{s}=\eta^{(s)}
\end{aligned}
$$

ただしここに

$$
\lambda=\frac{l^{3} e}{48 E I_{\mathcal{J}}}, \quad \mu=\frac{a\left(3 l^{2}-4 a^{2}\right) e}{48 E I_{\mathcal{\zeta}}}, \nu=\frac{a^{2}(3 l-4 a) e}{6 E I_{\mathcal{f}}}, \frac{1}{\rho_{c}}=E I_{c}, \frac{1}{\rho_{s}}=E I_{s}
$$

であつて, $\eta^{(c)}$ 抢よび $\eta^{(\boldsymbol{})}$ は横部材 $I_{f}$ が単独梁として単位長さ当り $q e$ なる等分布荷重を受けるときの centre girder および side girder の位置での撓みを示し

$$
\eta^{(c)}=\frac{5 q e l^{4}}{384 E I_{\digamma}}, \quad \eta^{(s)}=\frac{q e a\left(l^{3}-2 l a^{2}+a^{3}\right)}{24 E I_{\digamma}}
$$

となる。そこで今

および

$$
\left.\begin{array}{l}
\alpha_{1} \\
\alpha_{2}
\end{array}\right\}=\sqrt[4]{\frac{\lambda \rho_{s}+v \rho_{c}}{8\left(\lambda \nu-2 \mu^{2}\right)}\left\{1 \mp \sqrt{1-\frac{4 \rho_{c} \rho_{s}\left(\lambda v-2 \mu^{2}\right)}{\left(\lambda \rho_{s}+v \rho_{c}\right)^{2}}}\right\}}
$$


とおき，且つ問題の対称性を考虑に入れると（79）の一般解は次式で与えられる。

$\left.\begin{array}{l}y_{c}=C_{1} \cos \alpha_{1} z \cosh \alpha_{1} z+C_{2} \sin \alpha_{1} z \sinh \alpha_{1} z+C_{3} \cos \alpha_{2} z \cosh \alpha_{2} z+C_{4} \sin \alpha_{2} z \sinh \alpha_{2} z+\eta(c) \\ y_{s}=\beta_{1}\left(C_{1} \cos \alpha_{1} z \cosh \alpha_{1} z+C_{2} \sin \alpha_{1} z \sinh \alpha_{1} z\right)+\beta_{2}\left(C_{3} \cos \alpha_{2} z \cosh \alpha_{2} z+C_{4} \sin \alpha_{2} z \sinh \alpha_{2} z\right)+\eta^{(s)}\end{array}\right\}$

境界条件として $z= \pm l_{1} / 2$ にて $y_{c}=d y_{c} / d z=y_{s}=d y_{s} / d z=0$ とすれば

$$
\begin{aligned}
& C_{1}=\frac{\beta_{2} \eta^{(c)}-\eta^{(s)}}{\beta_{1}-\beta_{2}}-\frac{\sin \varphi_{1} \cosh \varphi_{1}+\cos \varphi_{1} \sinh \varphi_{1}}{\sin \varphi_{1} \cos \varphi_{1}+\sinh \varphi_{1} \cosh \varphi_{1}} \\
& C_{2}=\frac{\beta_{2} \eta(c)-\eta(s)}{\beta_{1}-\beta_{2}}-\frac{\sin \varphi_{1} \cosh \varphi_{1}-\cos \varphi_{1} \sinh \varphi_{1}}{\sin \varphi_{1} \cos \varphi_{1}+\sinh \varphi_{1} \cosh \varphi_{1}} \\
& C_{3}=-\frac{\beta_{1} \eta^{(c)}-\eta^{(s)}}{\beta_{1}-\beta_{2}}-\frac{\sin \varphi_{2} \cosh \varphi_{2}+\cos \varphi_{2} \sinh \varphi_{2}}{\sin \varphi_{2} \cos \varphi_{2}+\sinh \varphi_{2} \cosh \varphi_{2}} \\
& \left.C_{4}=-\frac{\beta_{1} \eta^{(c)}-\eta^{(s)}}{\beta_{1}-\beta_{2}} \frac{\sin \varphi_{2} \cosh \varphi_{2}-\cos \varphi_{2} \sinh \varphi_{2}}{\sin \varphi_{2} \cos \varphi_{2}+\sinh \varphi_{2} \cosh \varphi_{2}}\right)
\end{aligned}
$$

ただしここに

$$
\varphi_{1}=\alpha_{1} l_{1} / 2, \quad \varphi_{2}=\alpha_{2} l_{1} / 2
$$

また平均撓み $\bar{y}_{c}$ は $\bar{y}_{c}=\frac{2}{l_{1}} \int_{0}^{\frac{l_{1}}{2}} y_{c} d z$ として次式のごとくになる。

$$
\begin{aligned}
\bar{y}_{c}= & \eta^{(c)}+\frac{C_{1}}{2 \varphi_{1}}\left(\sin \varphi_{1} \cosh \varphi_{1}+\cos \varphi_{1} \sinh \varphi_{1}\right)+\frac{C_{2}}{2 \varphi_{1}}\left(\sin \varphi_{1} \cosh \varphi_{1}-\cos \varphi_{1} \sinh \varphi_{1}\right) \\
& +\frac{C_{3}}{2 \varphi_{2}}\left(\sin \varphi_{2} \cosh \varphi_{2}+\cos \varphi_{2} \sinh \varphi_{2}\right)+\frac{C_{4}}{2 \varphi_{2}}\left(\sin \varphi_{2} \cosh \varphi_{2}-\cos \varphi_{2} \sinh \varphi_{2}\right) \equiv \bar{\alpha} \eta(c)
\end{aligned}
$$

付録 4. 船底の振動に対する付加水質量

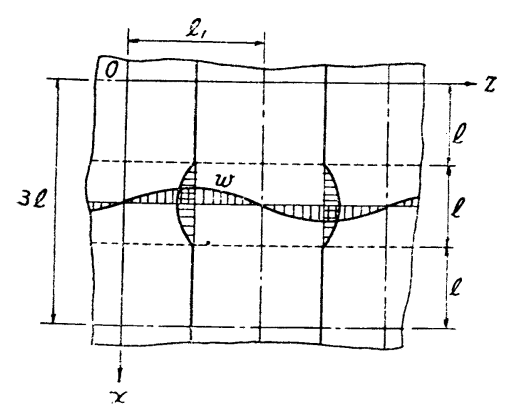

Fig. 25

船底を幅 $l$, 長さ $l_{1}$ の矩形板が船の長さ方向に無限に連続した ものと考兄, 長さ方向には間隔 $l_{1}$ 毎に nodal line を持つような撓 み変形を考える。また船底は幅の力向には有限長さ $l$ であるから, Fig. 25 のごとく $3 l \times l_{1}$ なる区画を考え， $x$ 方向には中央部 $l$ の 又に撓又変形を生じその前後の $l$ では撓みがないよ5な変形を考兵 れば，有限幅の板の運動が水に与える影響を近似的に算入すること ができる。

撓みの形を $w_{0}$ を定数として

$$
w=w_{0} f(x) \sin ^{-\frac{\pi z}{l_{1}}} \sin \omega t
$$

と括さ，f(x) を次のような函数とする。

$0 \leqq x \leqq l$ 怙よび $2 l \leqq x \leqq 3 l: f(x)=0, l \leqq x \leqq 2 l: f(x)=-\sin \frac{\pi x}{l}$

(90)を $-3 l \leqq x \leqq 3 l$ の領域で Fourier の sine 級数

$$
f(x)=\sum_{n=1}^{\infty} a_{n} \sin \frac{n \pi x}{3 l}
$$

に展開すれば (89) は

$$
w=w_{0} \sum_{n=1}^{\infty} a_{n} \sin \frac{n \pi x}{3 l} \sin \frac{\pi z}{l_{1}} \sin \omega t
$$

一方流体の速度ポテンシャル $\phi$ として

$$
\phi=\sum_{n=1}^{\infty} A_{n} a_{n} \sin \frac{n \pi x}{3 l} \sin \frac{\pi z}{l_{1}} e^{-\alpha_{n y}} \cos \omega t
$$

を考える。ここに $y$ は板の面に垂直な座標軸である。(93) が $\nabla^{2} \phi=0$ を満足する条件より

$$
\alpha_{n}^{2}=\left(\frac{n \pi}{3 l}\right)^{2}+\left(\frac{\pi}{l_{1}}\right)^{2} \quad(n=1,2,3, \cdots \cdots)
$$

板の表面 $y=0$ での境界条件 


$$
\frac{\partial \phi}{\partial y}=\frac{\partial w}{\partial t}
$$

により $A_{n}$ が定まり $\phi$ は次式のごとくになる。

$$
\phi=-w_{0} \omega \sum_{n=1}^{\infty} \frac{a_{n}}{\alpha_{n}} \sin \frac{n \pi x}{3 l} \sin \frac{\pi z}{l_{1}} e^{-\alpha_{n} y} \cos \omega t
$$

船底の場合は板の片側のみに水があるから，水の持つ運動エネルギー $T_{1}$ は

$$
T_{1}=-\frac{\rho}{2} \int_{0}^{3 l} \int_{0}^{l_{1}}[\phi]_{y=0} \frac{\partial w}{\partial t} d x d z
$$

として求められ，(92）扰よび（96）を入れて

$$
T_{1}=\frac{9}{8 \pi} \rho w_{0}^{2} \omega^{2} l^{2} l_{1}^{2} \cos ^{2} \omega t \sum_{n=1}^{\infty} \frac{a_{n}^{2}}{\sqrt{9 l^{2}+n l_{1}^{2}}}
$$

となる。一方船底自身の運動エネルギー $T$ は船底の重量を $M$ として

$$
T=\frac{1}{2} \frac{M}{l l_{1}} \int_{0}^{3 l} \int_{0}^{l_{1}}\left(\frac{\partial w}{\partial t}\right)^{2} d x d z=\frac{3}{8} M w_{0}^{2} \omega^{2} \cos ^{2} \omega t \sum_{n=1}^{\infty} a_{n}^{2}
$$

従つて周囲の水を含めた系全体の運動エネルギーは

$$
T+T_{1}=\frac{3}{8} w_{0}^{2} \omega^{2} \cos ^{2} \omega t \sum_{n=1}^{\infty} a_{n}^{2}\left[M+\frac{3}{\pi} \rho l^{2} l_{1}^{2} \frac{\sum_{n=1}^{\infty} \frac{a_{n}^{2}}{\sqrt{9 l^{2}+n l_{1}^{2}}}}{\sum_{n=1}^{\infty} a_{n}^{2}}\right]
$$

となりこれより付加水質量 $M_{1}$ は次式によつて与えられる。

$$
M_{1}=\frac{3}{\pi} \rho l^{2} l_{1} \sum_{n=1}^{\infty} \frac{a_{n}^{2}}{\sqrt{n+9\left(\frac{l}{l_{1}}\right)^{2}}} / \sum_{n=1}^{\infty} a_{n}^{2}
$$

この付加水質量 $M_{1}$ が船底に一様に分布するものと仮定して, 横方向に切出した単位幅の船底部分に対する付 加水質量を $M_{1}^{\prime}$ とすれば

$$
M_{1}^{\prime}=\frac{M_{1}}{l_{1}}=\frac{3}{\pi} \rho l^{2} \sum_{n=1}^{\infty} \frac{a_{n}^{2}}{\sqrt{n+9\left(\frac{l}{l_{1}}\right)^{2}}} / \sum_{n=1}^{\infty} a_{n}^{4}
$$

となり，これが船底相当梁の全長に対する付加水質量となる。 $n=16$ まで採つた場合の (100)は(91)の Fourier 係数 $a_{n}$ を計算して本文 (52) のごとく与えられる。 